\title{
Granulite-facies metamorphism at ca. 570-580 Ma in the Porangatu Granulite Complex, central Brazil: implications for the evolution of the Transbrasiliano Lineament

\author{
Metamorfismo da fácies granulito em 570-580 Ma \\ no Complexo Granulítico Porangatu, centro do Brasil: \\ implicações para a evolução do Lineamento Transbrasiliano \\ Paulo Sergio de Sousa Gorayeb ${ }^{1 *}$, Marcio Martins Pimentel ${ }^{2}$, \\ Richard Armstrong ${ }^{3}$, Marco Antonio Galarza ${ }^{1}$
}

\begin{abstract}
The Porangatu Granulite Complex is exposed in the central part of the Neoproterozoic Tocantins province in central Brazil, along the boundary between the Brasília Belt to the east and the Araguaia Belt to the west. This is part of the transcontinental Transbrasiliano-Kandi shear system. The complex includes garnet-rich enderbite and charnockite, high-grade gneisses as well as lenses of garnet-bearing mafic granulite or amphibolites, and in situ anatectic charnockite, elongated in the NNE-SSW direction along the Talismã Shear Zone (TSZ). These rocks represent suites of ortho-derived rocks of calc-alkaline affinity and small contributions of tholeiitic basalts and aluminous paragneisses. The structural framework records thrust components probably related to the early stages of an oblique collision during the evolution of Neoproterozoic Brasiliano orogens, and can be understood as involving a collisional system of two crustal blocks, initially with thrust components which in its final stage evolved to a transcurrent system with dextral movement. This led to intense imbrication, generation of mylonitic foliation, stretching lineation, tectonic banding and rotation of structures and minerals. The heterogeneous and progressive ductile deformation was accompanied by metamorphic re-equilibrium in late Neoproterozoic time. Granulite facies conditions reached a metamorphic maximum at temperature and pressure above $850^{\circ} \mathrm{C}$ and $10 \mathrm{kbar}$, in an almost anhydrous environment, with or without anatexis. Zircon U-Pb SHRIMP analyses for two selected rock samples indicated the combined age of $580 \pm 7 \mathrm{Ma}$ for a charnockite and $548 \pm 48 \mathrm{Ma}$ for a mafic granulite from which the charnockite is throught to have been derived. The mafic granulite contains zircon grains of ca. $2.1 \mathrm{Ga}$, indicating Paleoproterozoic igneous protoliths involved in Neoproterozoic high-grade metamorphism. In addition, older inherited zircon grains of ca. 3.1 and $2.0 \mathrm{Ga}\left({ }^{207} \mathrm{~Pb} /{ }^{206} \mathrm{~Pb}\right.$
\end{abstract}

RESUMO: O Complexo Granulitico Porangatu está exposto na porção central da Província Tocantins, do Neoproterozoico, no centro do Brasil, ao longo da fronteira entre o Cinturão Brasilia, a leste, e o Cinturão Araguaia, a oeste. Esta regiāo faz parte do sistema de cisalhamento transcontinental Transbrasiliano-Kandi. O complexo inclui enderbitos e charnockitos ricos em granada, gnaisses de alto grau metamórfico, bem como lentes de granada granulitos máficos ou granada anfibolitos, e charnockitos anatéticos in situ, o qual forma corpos alongados na direção NNE-SSW, ao longo da Zona de Cisalhamento Talismã (ZCT). Esse conjunto de rochas representam suites de rochas ortoderivadas de afinidade cálcio-alcalina e pequenas contribuiçōes de basaltos tholeiticos e paragnaisses aluminosos. O quadro estrutural registra componentes de cavalgamento relacionados provavelmente com os estágios iniciais de uma colisäo oblíqua durante a evolução dos orógenos Brasilianos do Neoproterozoico e pode ser compreendido como envolvendo um sistema colisional de dois blocos crustais, inicialmente com componentes de cavalgamento que evoluiu em sua fase final para um sistema transcorrente com cinemática dextral. Isso levou à intensa imbricação, geraçẫo de foliação milonítica, lineação de estiramento, bandamento tectônico e rotação de estruturas e minerais. A deformação dúctil heterogênea e progressiva foi acompanhada por reequilibrio metamórfico no Neoproterozoico tardio, que atingiu condiçōes metamórficas máximas na fácies granulito a temperatura e pressão acima de $850^{\circ} \mathrm{C} e$ 10 kbar, respectivamente, em ambiente quase anidro, atingindo a anatexia. As análises U-Pb SHRIMP em zircão realizadas em duas amostras de rochas selecionadas indicaram idade combinada de $580 \pm 7$ Ma para um charnockito e $548 \pm 48$ Ma para um granulito máfico do qual o charnockito foi derivado. O granulito máfico contém cristais de zircão datados de 2,1 Ga, indicando protólito ígneo do Paleoproterozoico envolvidos no metamorfismo de alto grau no Neoproterozoico. Além disso, os grãos de zircäo mais antigos herdados de 3,1 e 2,0 Ga (idades ${ }^{207} \mathrm{~Pb} \mathrm{P}^{06} \mathrm{~Pb}$ ) em

${ }^{1}$ Instituto de Geociências, Universidade Federal do Pará - UFPA, Belém (PA), Brazil. E-mails: gorayebp@ufpa.br; antogt@ufpa.br 2Instituto de Geociências, Universidade de Brasília - UnB, Brasília (DF), Brazil. E-mail: marcio@unb.br ${ }^{3}$ Research School of Earth Science, Australian National University - Canberra, Australia. E-mail: richard.armstrong@anu.edu.au *Corresponding author.

Manuscript ID: 20160097. Received in: 08/12/2016. Approved in: 03/27/2017. 
ages) in charnockite also confirm the existence of older Archaean and Paleoproterozoic material in this region, possibly derived from the Goiás Massif. A $0.88 \mathrm{Ga}$ inherited zircon grain is suggestive of derivation from the Goiás Magmatic Arc. This Neoproterozoic age for the high-grade metamorphism is substantially younger than those reported for other granulites in the Brasília Belt (ca. 0.65 Ga), suggesting that the Porangatu Granulite Complex is more probably associated with the evolution of the younger Araguaia Belt. The new field, structural, petrographic and geochronological data suggest that the Porangatu Granulite Complex was involved in a high-temperature ductile strike-slip shear zone juxtaposing terrains of different ages (Archaean, Paleoproterozoic, Neoproterozoic), crustal nature and level (lower and middle continental crust), strongly reworked during the final stages of the Brasiliano orogeny, and represents the exposed roots of the Tocantins orogen.

KEYWORDS: High-grade metamorphism; Porangatu Granulite Complex; SHRIMP U-Pb zircon geochronology; Transbrasiliano Lineament; Tocantins Orogen.

\section{INTRODUCTION}

The Porangatu Granulite Complex (Gorayeb 1996a) is exposed in the central part of the Tocantins Province, a large Neoproterozoic orogenic area in central Brazil formed during the collision between the Amazonian and São Francisco-Congo cratons. The province is formed by three main belts: the Brasilia Belt, in the eastern half of the province; the Araguaia Belt, along the eastern margin of the Amazonian Craton; and the Paraguay Belt, in the southwestern part of the province (Fig. 1). Granulitic rocks are exposed in several areas of the Brasilia Belt (Dardenne 2000) and have been the object of recent mapping and geochronological studies (Dantas et al. 2007).

The Porangatu granulite belt is exposed in an area of approximately $80 \times 25 \mathrm{~km}$, extending in a NNE-SSW direction between the westernmost exposures of the Paraguay Belt, the Goiás magmatic arc, the Brasília Belt and the metasedimentary rocks of the Araguaia Belt to the north, which forms a larger geotectonic unit (Tocantins orogen) and could represent the roots of this Neoproterozoic orogen. The granulitic rocks appear as lens-shaped bodies along the $10 \mathrm{~km}$-wide Talismã Shear Zone (TSZ), comprising mainly high-grade mylonitic gneisses. This is part of the transcontinental transcurrent dextral shear zone system, known as the Transbrasiliano Lineament (TBL), which crosses much of the South American continent (Schobbenhaus Filho et al. 1975, Cordani et al. 2013). The mega-shear zone is exposed from Argentina and Paraguay, through central Brazil, and may be traced through northeastern Brazil into western Africa, where it is known as the Kandi Lineament. The total length of the lineament is estimated to be approximately $4,000 \mathrm{~km}$, making it the most extensive shear zone on Earth (Schobbenhaus Filho et al. 1975, Trompette 1994, Oliveira \& Mohiak 2003, Arthaud et al. 2008, Attoh \& Brown 2008, Santos et al. 2008b, Cordani et al. 2013, Cacama et al. 2015). charnockito também confirma a existência de material Arqueano e Paleoproterozoico nesta região, possivelmente derivado do Maciço de Goiás. Um grão de zircáo herdado de 0,88 Ga é sugestivo de derivação do Arco Magmático de Goiás. Essa idade neoproterozoica para o metamorfismo de alto grau é substancialmente mais jovem do que a relatada para outros granulitos do Cinturão Brasília (cerca de 0,65 Ga), sugerindo que o Complexo Granulítico Porangatu está mais provavelmente associado à evolução do Cinturáo Araguaia mais jovem. Os novos dados de campo, estruturais, petrográficos, e geocronológicos, sugerem que o Complexo Granulítico Porangatu foi envolvido em uma expressiva zona de cisalhamento transcorrente dúctil estabelecida em alta temperatura, que justapôs unidades de rochas de diferentes idades (Arqueano, Paleoproterozoico, Neoproterozoico), naturezas e niveis crustais (crosta continental inferior e média) fortemente retrabalhadas nos estágios finais da orogenia Brasiliano e representam as raizes expostas do Orógeno Tocantins.

PALAVRAS-CHAVE: Metamorfismo de alto grau; Complexo Granulitico Porangatu; Geocronologia U-Pb SHRIMP em zircáo; Lineamento Transbrasiliano; Orógeno Tocantins.

The main objective of the present study, based on the petrographic, structural and geochronological characteristics of high-grade metamorphic rocks, is to enhance understanding of the evolution of this granulite belt and of its significance in the development of the TBL, as well as in the tectonic evolution of the Araguaia and Brasilia belts. Although other granulite complexes in central Brazil have been investigated in some detail — for example the Anápolis-Itauçu and the Uruaçu complexes (Fischel et al. 1998) —, the high-grade metamorphic rocks of Porangatu remain poorly known. Therefore, the main focus of the present study is to investigate their field, structural and petrographic characteristics, as well as their age.

\section{GEOLOGICAL CONTEXT}

In the eastern part of the Tocantins Province (Fig. 1), the Brasília Belt includes:

1. several metasedimentary units deposited on a Paleoproterozoic sialic basement (Almeida et al. 1981, Fuck et al. 1993, Pimentel et al. 2000, 2011);

2. one small allochthonous sialic fragment made dominantly of Archean trondhjemite-tonalite-granodiorite (TTG) terranes and greenstone belts (the Goiás Archean block of Jost et al. 2013);

3. three large mafic-ultramafic complexes (Barro Alto, Niquelândia and Cana Brava; Ferreira Filho et al. 2010);

4. the Neoproterozoic Goiás Magmatic Arc in the west (for a brief review see Laux et al. 2005, Brito-Neves et al. 2014);

5. a large Neoproterozoic high-grade terrain known as the Anápolis-Itauçu complex, interpreted as the roots of the Brasília orogen (Piuzana et al. 2003, Giustina et al. 2011).

The Araguaia Belt forms the central and northern parts of the Tocantins Province, representing a N-S collisional orogen 
extending for more than $1,200 \mathrm{~km}, 150-200 \mathrm{~km}$ in width. It consists dominantly of metasedimentary units, associated with ophiolite, exposed along the eastern margin of the Amazonian Craton (Alvarenga et al. 2000, Moura et al. 2008, Gorayeb et al. 2008). The orogen started its evolution at ca. $870 \mathrm{Ma}$ with the deposition of the Araguaia basin and the formation of the ophiolitic suites represented by Morro do Agostinho, Quatipuru and Serra do Tapa suites (Kotschoubey et al. 2005, Paixão et al. 2008, Miyagawa \& Gorayeb 2013, Paixão \& Gorayeb 2014, Barros 2015). The main orogenic phase took place at ca. $550 \mathrm{Ma}$, with tectonic transportation towards the Amazonian Craton, accompanied by a metamorphism that increases gradually from anchimetamorphism, in the west, to middle-amphibolite facies, in the east, with emplacement of syn- to late-orogenic granites (Alvarenga et al. 2000).

The Paraguay Belt is a fold-and-thrust belt established along the southern margin of the Amazonian Craton and to the east of the Rio Apa cratonic block. It forms a 1,000 km long curved orogen convex toward the cratonic areas. It shows polyphase deformation with large-scale linear synforms and antiforms, as well as reverses and thrust faults. Magmatic rocks are very scarce and represented mostly by post-orogenic K-rich granite intrusions (Almeida 1984, Alvarenga et al. 2000, McGee et al. 2012). The belt comprises distinct

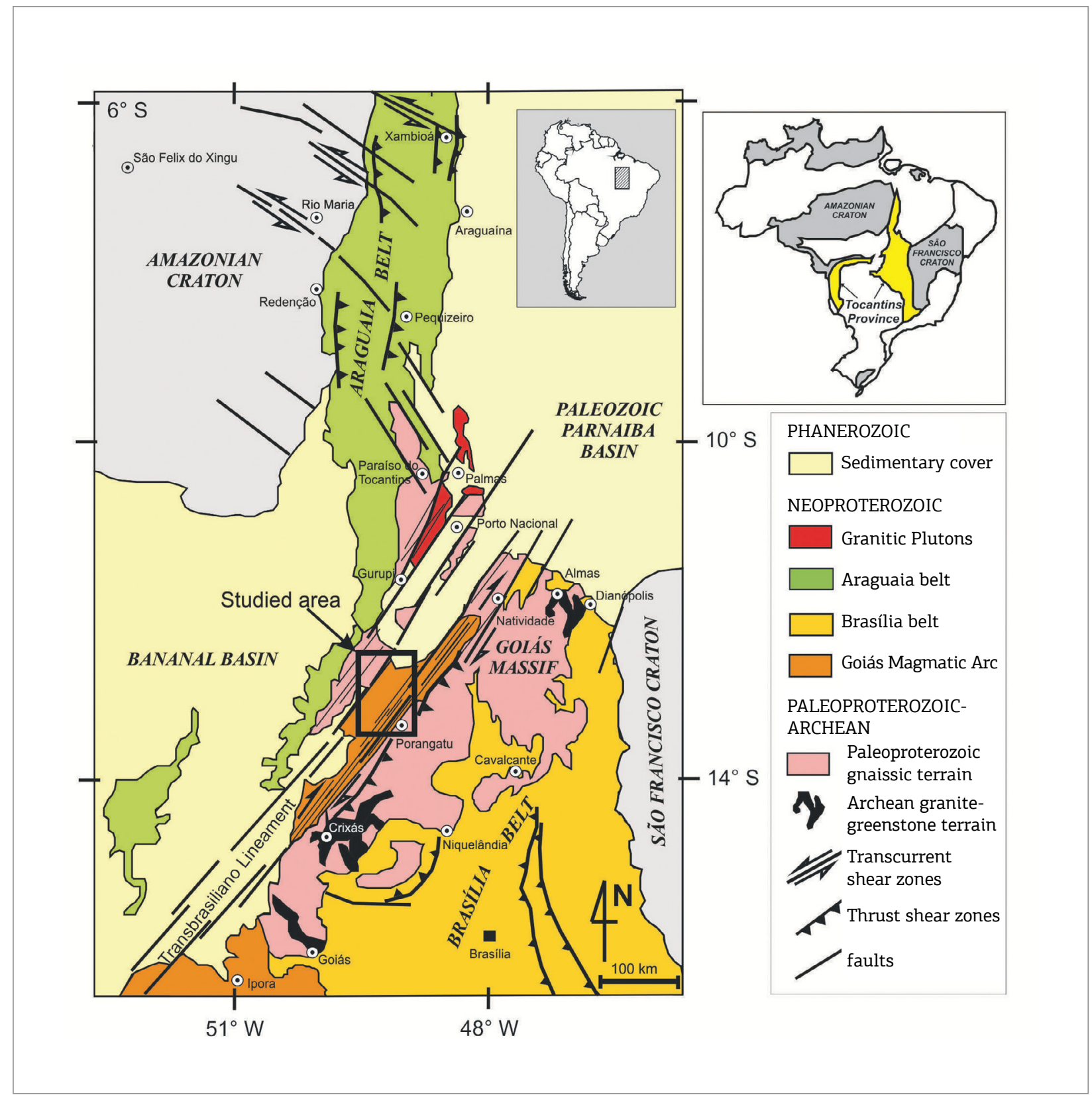

Figure 1. Geological map of the Tocantins Province, adapted from Gorayeb et al. (2013). 
structural zones: a sedimentary platform cover, an unmetamorphosed folded external zone, a metamorphic (greenschist facies) internal zone, and granite plutons (Alvarenga \& Trompette 1993). Ediacaran fauna found in rocks of the external zone of the southern part of the belt, as well as $\mathrm{U}-\mathrm{Pb}$ SHRIMP data in zircon grains of volcanic tuffs, indicate a depositional age of ca. $543 \mathrm{Ma}$ (Boggiani et al. 2010).

The Goiás Magmatic Arc, in the western part of the Brasília Belt, comprises calc-alkaline volcano-sedimentary sequences associated with plutonic counterparts, represented mainly by tonalite and granodiorite. The arc was initiated at ca. $900 \mathrm{Ma}$ with the growth of intra-oceanic island arcs, comprising meta-basalt, meta-andesite, meta-dacite and meta-rhyolite, as well as the corresponding plutonic rocks. These rocks display primitive geochemical and isotopic characteristics with initial $\varepsilon_{\mathrm{Nd}}$ values mostly ranging between +6 and +3 , and $\mathrm{Nd} \mathrm{T}_{\mathrm{DM}}$ ages between 0.8 and $1.1 \mathrm{Ga}$ (Pimentel et al. 1991, 1997, 2000; Pimentel \& Fuck 1992, Laux 2004, Laux et al. 2005). Trace element and isotopic data suggest that some of the tonalites are similar to Phanerozoic adakites (Pimentel et al. 1991, 1997). Arc magmatism was two pulses at ca. $900-800 \mathrm{Ma}$ and ca. $640 \mathrm{Ma}$, and the younger rocks tend to be more evolved geochemically and isotopically, presenting evidence of reworking of older sialic crust. The main metamorphic event took place at ca. $630 \mathrm{Ma}$, as indicated by $\mathrm{U}-\mathrm{Pb}$ titanite data and $\mathrm{Sm}-\mathrm{Nd}$ garnet ages (Laux et al. 2005). This is similar to the regional metamorphic event observed in several other parts of the Brasília Belt, and has been interpreted as representative of the final closure of the ocean and continental collision (for a review see Cordani et al. 2013).

The TBL is part of the transcontinental transcurrent dextral shear zones that extends across a large part of the South American continent with records in Argentina and Paraguay, across central to northwestern Brazil in the Atlantic coastal area of Ceará. In the central portion of Brazil, the lineament is represented by extensive shear zones and its ramifications, with dextral movement, consisting of mylonite affecting protoliths of different nature, origin and age, such as the Tocantins Shear Belt (Gorayeb 1996a, 1996b, Gorayeb et al. 2000) and the TSZ (Gorayeb 1996a, Dantas et al. 2007). The TBL and its extension in West Africa were first recognized by Kroener \& Cordani (2003), Caby (2003) and Cordani et al. (2013).

Several grabens associated with fault systems are identified. They were reactivated from latest Palaeozoic to Quaternary times. The studies of Oliveira \& Mohiak (2003) and Santos et al. (2013) demonstrate that the TBL influenced the formation and deposition of the Palaeozoic-Mesozoic Parnaiba Basin.

The Kandi Lineament in Africa (Cordani et al. 2013, Caby 2003, Kroener \& Cordani 2003) is an extension of the SobralPedro II Lineament (Gama Junior et al. 1988, Gorayeb and Abreu 1998, Cavalcante et al. 2003, Gorayeb \& Lima 2014).
In the northwest of the Borborema Province, the Neoproterozoic evolution started with an early collision associated with the closure of the Pharusian-Goiás ocean at 620-600 Ma and generalized crustal thickening, marked by the development of high-grade metamorphic rocks and high-T thrusting foliation, defining a West Gondwana orogen. This was subsequently reactivated by a set of transcurrent dextral shear zones, forming the Transbrasiliano-Kandi strike-slip belt, which acted as a transform plate boundary, allowing the closure of the ocean and collision with the São Francisco Craton at ca. 590 Ma. Interactions between the two collisions between 590 and $570 \mathrm{Ma}$ and continuous cratonic indentation led to the province-wide switch to transcurrent system and block escape, generally to the NE, associated with wide magmatism and regional rotation of the maximum shortening axis (Araujo et al. 2014). This situation is similar to that of the Tocantins Province, which extends under the Parnaiba Basin.

\section{RESULTS}

\section{Geology and tectonics of the Porangatu-Alvorada region}

In the Porangatu-Alvorada region, high-grade metamorphic rocks may be grouped into two main litho-structural units:

1. the Gneissic-supracrustal terrain and

2. the Porangatu Granulite Complex within the TSZ, just to the west of the Serra Azul Granitoid (Fig. 2).

The initial cartographic studies were carried out by the Brazilian Geological Survey (CPRM) through the Porangatu Project (Machado et al. 1981), where the main lithostratigraphic units of the region were delimited and defined, followed by the cartographic and petrographic studies of Gorayeb (1996a), and the mapping in more detail executed by Dantas et al. (2007).

The gneissic-supracrustal terrain occupies a large area east of the Serra Azul-Cajueiro-Talismã Lineament, which represents the boundary between two crustal terranes within the ductile shear zone; according to the $\mathrm{Sm}-\mathrm{Nd}$ isotopic data reported by Dantas et al. (2006), it belongs to the Goiás Magmatic Arc. It comprises mainly migmatized orthogneisses of tonalitic, quartz dioritic and granitic composition, as well as paragneisses, micaschists bearing biotite, garnet and staurolite, amphibolites, calc-silicate rocks, quartzites, banded iron rock (BIF) and meta-ultramafic rocks.

The Porangatu Granulite Complex is exposed to the west of the Serra Azul-Cajueiro Lineament, within the TSZ, 


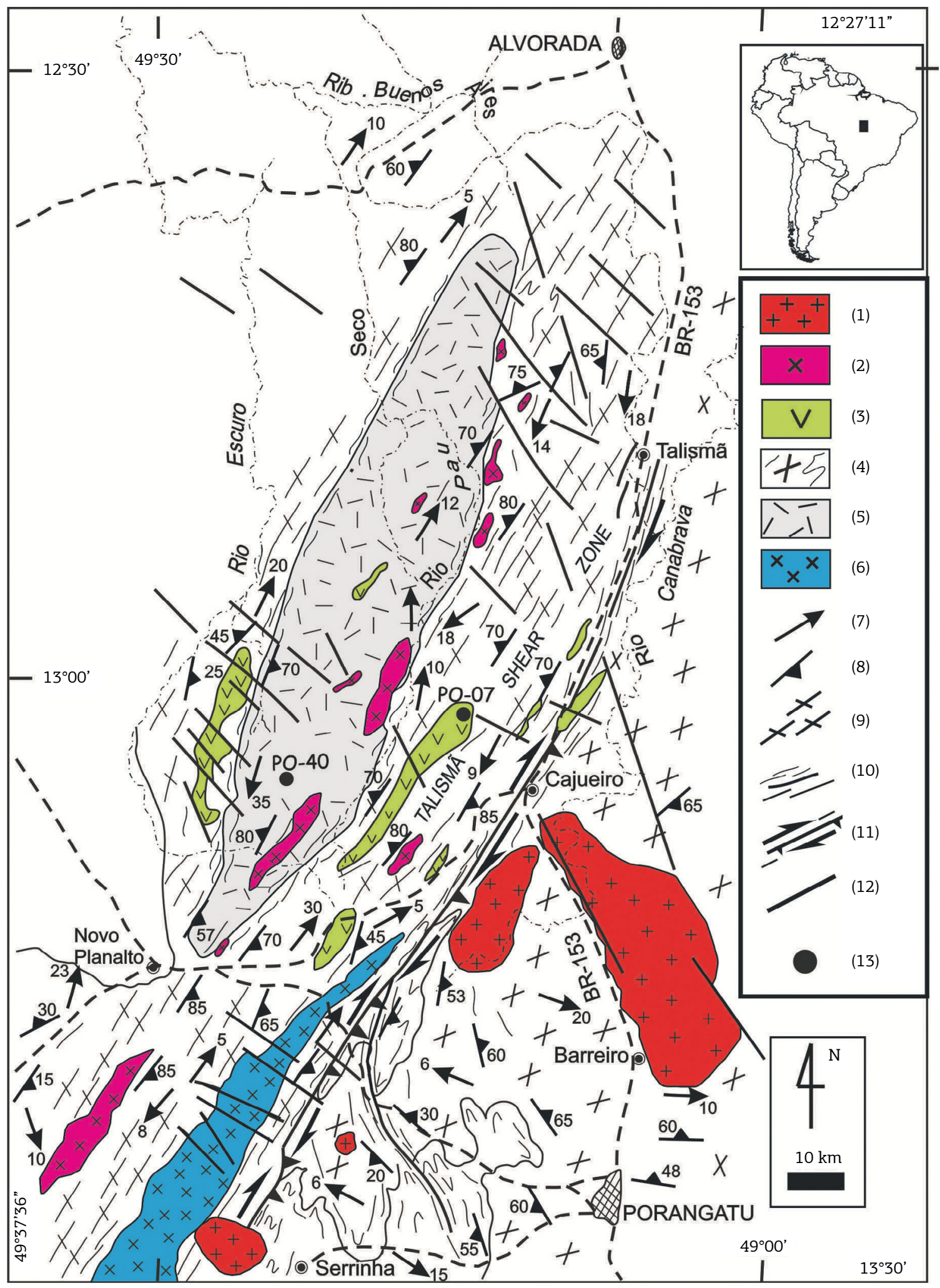

Figure 2. Geological map of the Porangatu-Alvorada region displaying the main geological units: (1) Post-tectonic granites; (2) Pau Seco granitoid suite; (3) Amphibolite bodies; (4) Gneissic-supracrustal complex; (5) Porangatu Granulite Complex; (6) Serra Azul granitoid suite; (7) Talismã Shear Zone (mylonitic para- and orthogneises, garnet-pyroxene amphibolites, mylonític granites and mylonitic granulites); (8) Structural trends; (9) Obliquethrust shear zone; (10) Faults; (11) Foliation; (12) Stretching lineation; (13) Dated samples. 
and forms an $80 \times 25 \mathrm{~km}$ elongated complex in the $\mathrm{N} 25^{\circ} \mathrm{E}$ direction (Fig. 2). The rock units form lens-shaped bodies and the main rock types are garnet-rich enderbitic, charno-enderbitic and charnockitic granulite, and less abundant garnet mafic granulite and biotite-garnet mylonitic gneiss. Amphibolite and mafic granulite form large lenses such as the Bocaina and Barreirinho Vermelho amphibolites, as well as small dismembered boudins mixed with mylonitic orthoand paragneisses. These rocks represent a suite of ortho-derived rocks of calc-alkaline affinity and small contributions of tholeiitic basalts and rare garnet paragneisses. Another type of charnockite forms small ( $\mathrm{cm}$ to $\mathrm{m}$ ) irregular bodies of leucosome as veins or patchy migmatitic structures within the enderbitic and mafic granulites, and represents in situ anatexis during high-grade metamorphism.

The Talismã Shear Zone (TSZ) extends for at least $25 \mathrm{~km}$ in the $\mathrm{N} 20-30^{\circ} \mathrm{E}$ direction, representing a zone of strong tectonic mobility juxtaposing terrains of different ages and crustal levels (lower and middle continental crust). In the southern part of the area, the Archean Serra Azul Granitoid (Dantas et al. 2006, 2007) forms a large lens representing a crustal slice tectonically interleaved with other TSZ rock units. Similarly, several smaller and elongated syn-tectonic granites are known, such as the Pau Seco Granitoid Suite (Fig. 2, 3A, B).

The main structural features are the mylonitic foliation and tectonic transposition banding, as well as the strong stretching lineation. Noteworthy is the strong linearity of the structural features displayed by the rocks, which were transformed into L- and L-S tectonites (Fig. 3C). The foliations generally have NNE-SSW trends with high dips, predominantly to the SE. The stretch lineation has low dip, around $0^{\circ}$ to $21^{\circ}$ to the NE (predominantly) or SW quadrants (Fig. 2). The tectonic kinematic indicators, developed in high-temperature gneiss tectonites, are defined by the stretching, flattening and rotation of sigmoidal porphyroclasts of feldspars, pyroxene and garnet, and pressure shadows in asymmetric patterns (Fig. 3); anastomosing mylonitic foliation with S-C foliation, and intrafolial folds in Z-patterns.

In addition, inflections of foliation and dragfolds identified at the macroscale were caused by the curving of supracrustal rock structures near the TSZ, such as Serra Verde to NW of Porangatu (Fig. 2). All these features reaffirm the evolution of a continental transcurrent shear system with dextral kinematics in this region, similar to that recognized in the Porto Nacional High-Grade Metamorphic Complex to the north (Gorayeb 1996b, Gorayeb et al. 2000), in the Cariré Granulite Belt (Gorayeb \& Abreu 1989) and the Macaco Granulite body (Gorayeb \& Abreu 1998), northwest of Borborema Province.

The heterogeneous and progressive ductile deformation was accompanied by re-equilibrium in metamorphic conditions of upper-amphibolite or granulite facies. This led to intense imbrication, generation of mylonitic foliation, stretch lineation, tectonic banding and rotation of structures and minerals (Fig. 3).

The gneiss-migmatite-supracrustal domain, east of the Serra Azul-Cajueiro Lineament presents very different structural behavior, in which the foliation shows approximately N-S direction with low to medium dip $\left(8-35^{\circ}\right)$ to ESE and WSW. The complex structural pattern is due to folding and drags, and to the rotation of these structures in the vicinities of the TSZ (Fig. 2). This structural framework records thrust components probably related to the early stages of an oblique collision during the evolution of Neoproterozoic Brasiliano orogens in this portion of the Tocantins Province. Thus, the tectonic evolution of the region can be understood as involving a collisional system of two crustal blocks, initially with thrust components which in its final stage evolved to a transcurrent system with dextral movement.

\section{Petrography and metamorphism of the granulitic rocks}

Enderbitic and charnoenderbitic (leucoenderbites) granulite are the most abundant rock types in the Porangatu Complex. They are generally homogeneous, with only a very weak banding, except for some local shear zones where mylonitic textures are recognized. They are normally finegrained rocks, greenish to gray, and locally with brownish to red spots due to the presence of garnet (Fig. 4A, 4B, 5A, $5 \mathrm{~B})$. They normally contain decimetric to metric enclaves of mafic granulites and are composed of plagioclase, alkali-feldspar, quartz, orthopyroxene and garnet and minor biotite, zircon, apatite and opaque minerals.

In the enderbites and charnoenderbites, oligoclase-andesine $\left(\mathrm{An}_{28-39}\right)$ shows antipertitic intergrowth and albite or albite-pericline twinning, although, in many cases twinning has been erased by deformation. Antipertitic texture is formed by small lamellae of alkali feldspar and parallel bands or rectangular patches, following the plagioclase cleavage. Myrmekitic textures occur along the contacts between plagioclase and alkali feldspar, and become more common in deformed zones. Alkali feldspar is a minor constituent, ranging in abundance from 0 (enderbites) to $30 \%$ modal (charnoenderbites). Twinning is faint or absent and they present perthitic texture (mesoperthite). Quartz is abundant and exhibits strong undulose extinction in larger crystals or polygonal recrystallized aggregates. Orthopyroxene is less deformed and frequently constitutes relict crystals, partially altered to green or brown biotite. Clinopyroxene is rare and is partially altered to light green amphibole. Garnet is abundant (5 to $15 \%$ modal) and occurs as porphyroblasts and poikiloblastic crystals with irregular contacts and plagioclase, quartz, apatite and biotite inclusions; idioblastic hexagonal crystals are not as common. Biotite is commonly 
present and in general defines a weak foliation. Two generations of biotite are recognized: one is primary with reddish-brown strong pleochroism, and the other is secondary, after orthopyroxene, presenting weak pleochroism. The first generation represents crystals which are stable at the granulite facies and the second is a retrograde mineral phase.
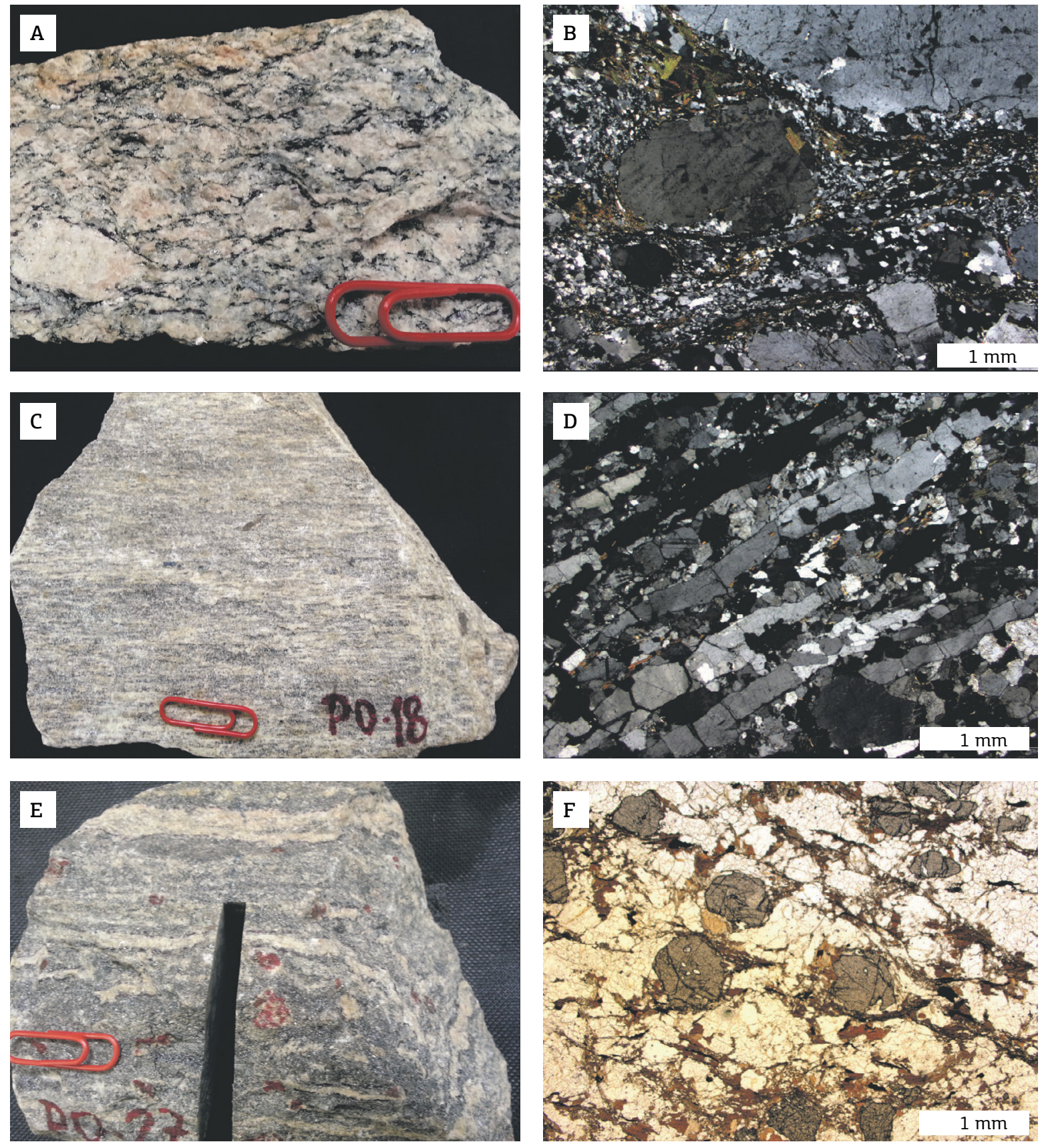

Figure 3. Microstructural features of paragneisses and granitoids of the studied area: (A, B) Augen alkalifeldspar porphyroclasts involved by anastomosed milonitic foliation of in a fine comminuted aggregate of quartz-feldspar matrix of the middle-temperature mylonite (Pau Seco Granite); (C, D) Strong lineation and ribbon quartz together with plagioclase and microcline in striped leucogneiss, defining the high-temperature mylonite (L-tectonite) along the Talismã Shear Zone; (E) Porphyroblastic garnet gneiss with neosome veins; (F) Rotated garnet porphyroblasts (dextral) enveloped by the anastomosed foliation defined by biotite and quartzfeldspar aggregates in paragneiss of the Porangatu Granulite Complex. Optical conditions: F - parallel polarizers; B and D - crossed polarizers. 
Charnockite forms small ( $\mathrm{cm}$ to $\mathrm{m}$ ) irregular bodies or leucosome veins within the enderbitic and mafic granulites; they are coarse-grained, highly leucocratic, isotropic and present greenish-gray colour, sometimes with a bluish tint given by blue quartz (Fig. 6A, 6B). The mesoperthite alkali feldspar forms relatively large crystals (up to $3 \mathrm{~cm}$ ) with rounded inclusions of quartz with string and patch perthitic intergrowth. The plagioclase is antiperthitic oligoclase-andesine $\left(\mathrm{An}_{24-35}\right)$, present albite and pericline twinning. Orthopyroxene is rare and mostly altered to amphibole and biotite.

Mafic granulite is the least abundant rock type in the Porangatu complex and in some cases occurs as enclaves in enderbite and charnoenderbite. It is fine-grained, equigranular, and presents a polygonal granoblastic texture (Fig. 7). It contains plagioclase, orthopyroxene, clinopyroxene, garnet and hornblende. Accessory minerals are apatite, zircon, rutile and opaque minerals.
Plagioclase varies compositionally between andesine-labradorite $\left(\mathrm{An}_{37-54}\right)$ and bytownite $\left(\mathrm{An}_{73}\right)$, presenting huttenlocher intergrowth (Smith \& Brown 1974, Ribbe 1983), a characteristic of high temperature Ca-plagioclase.

Orthopyroxene and clinopyroxene (diopside) are partially altered to hornblende. Two generations of hornblende are recognized: one is in equilibrium with pyroxenes and the other is the product of retrograde reaction.

Garnet forms coronitic microstructures and, in some cases, displays honeycomb-type texture surrounding plagioclase, amphibole or pyroxene grains formed by the reaction $\mathrm{Pl}+\mathrm{Cpx}_{1}(\mathrm{Opx})=\mathrm{Grt}+\mathrm{Cpx}_{2}+\mathrm{Qtz}$, typical of high-pressure metamorphism (Bard 1980, Best 1982, De Waard 1965, Harley 1985). In some other cases, the progression of this reaction forms larger poikiloblastic crystals with abundant inclusions of orthopyroxene, plagioclase and opaque minerals.
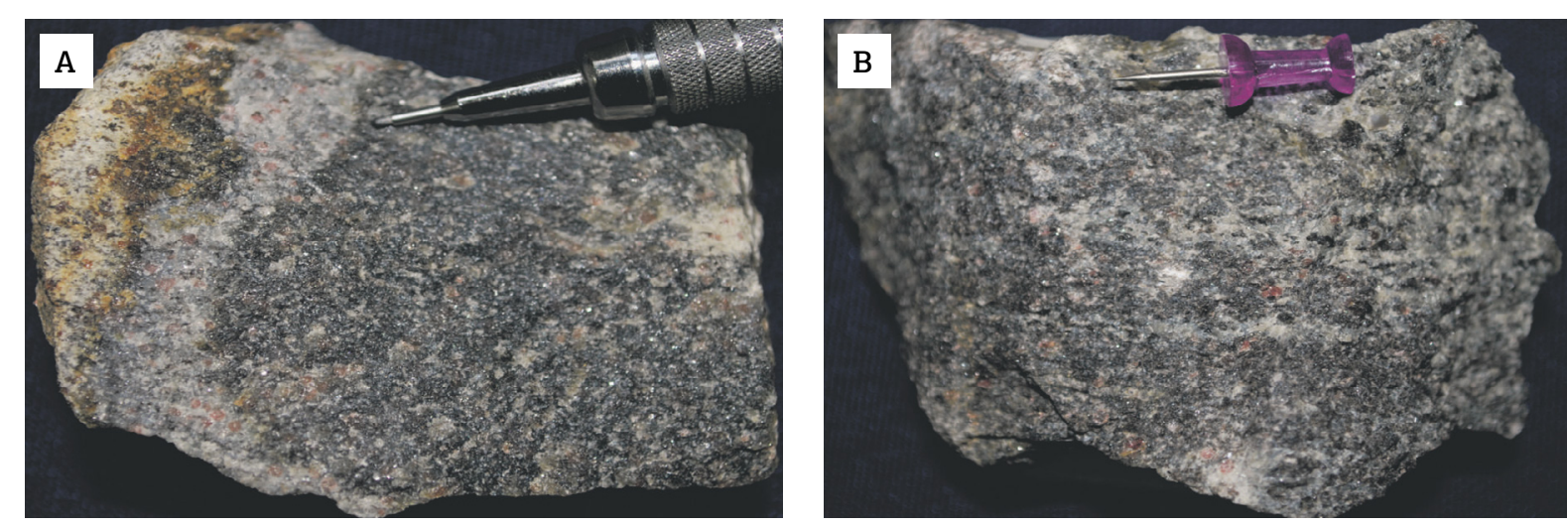

Figure 4. Hand specimen aspects of garnet enderbite of Porangatu Granulite Complex: (A) Isotropic texture in garnet-rich, fine-grained granulite; (B) Coarse-grained garnet charnockite leucosome forming irregular masses in the finer-grained enderbite.
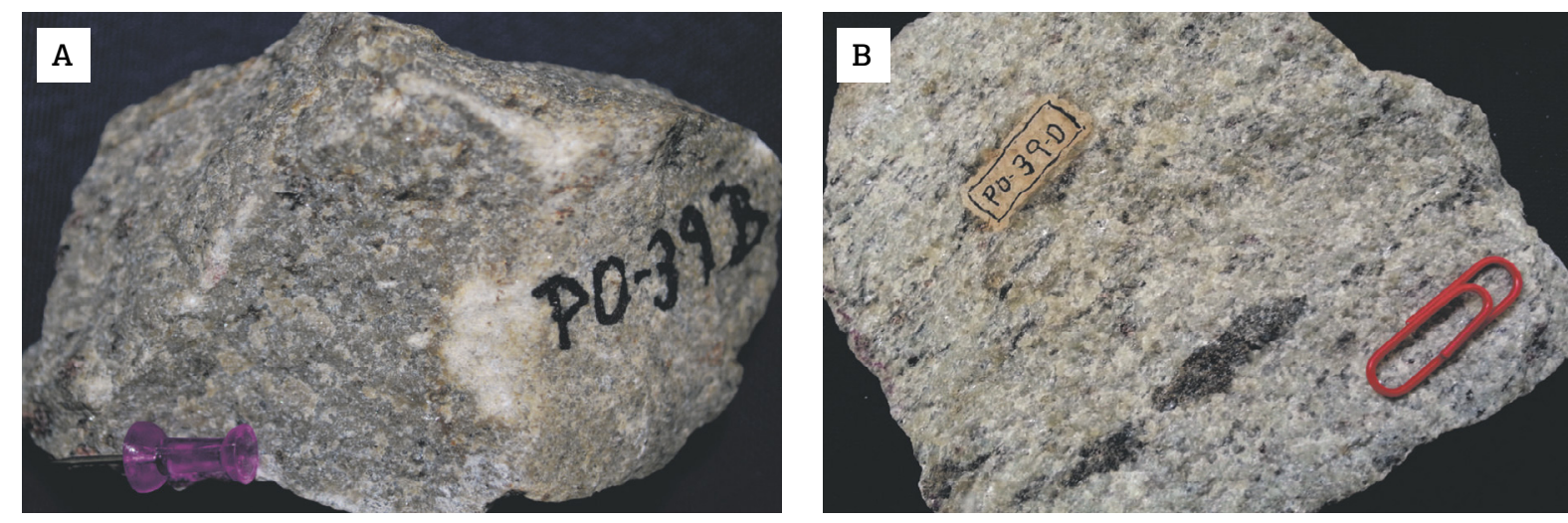

Figure 5. General aspects of garnet-bearing leuco-enderbite of Porangatu Granulite Complex: (A) Isotropic texture of fine-grained garnet granulite; (B) Slightly oriented biotite and garnet aggregates. 

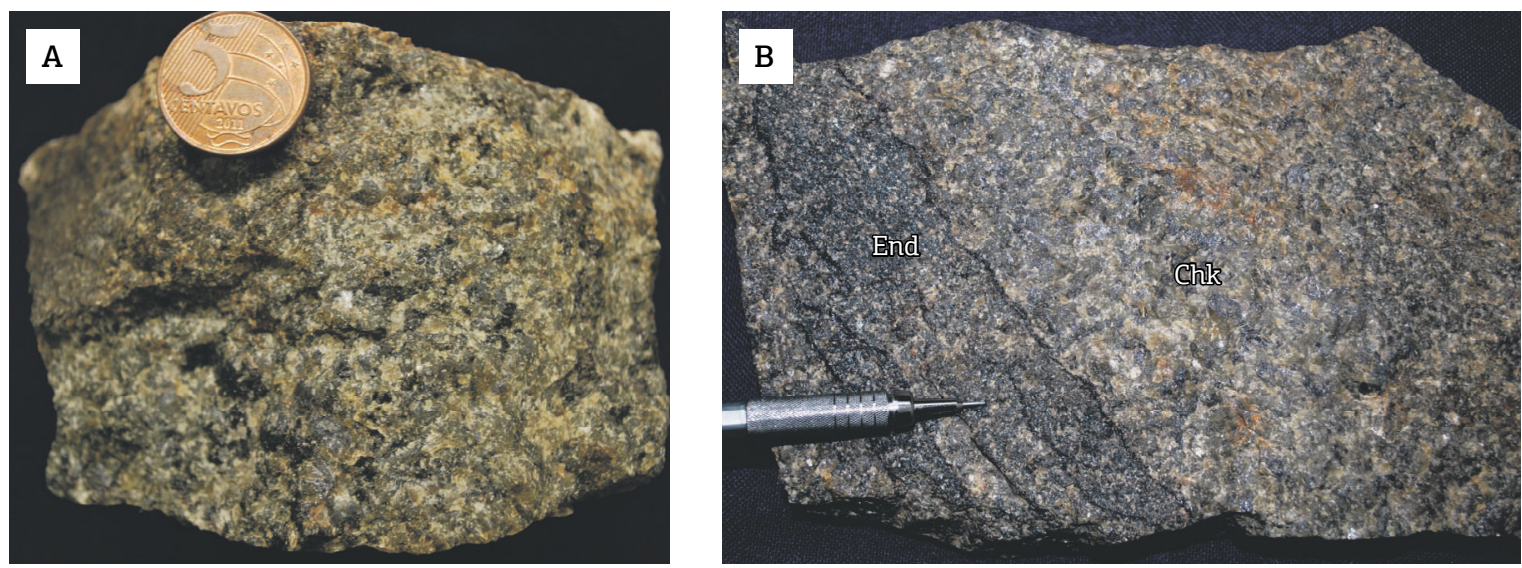

Figure 6. Hand specimens of the charnockite veins and irregular masses (Chk) of Porangatu Granulite Complex, showing their greenish colour and coarse-grained aspect with blue quartz (A) and fine-grained enclaves of the garnet enderbite (B).
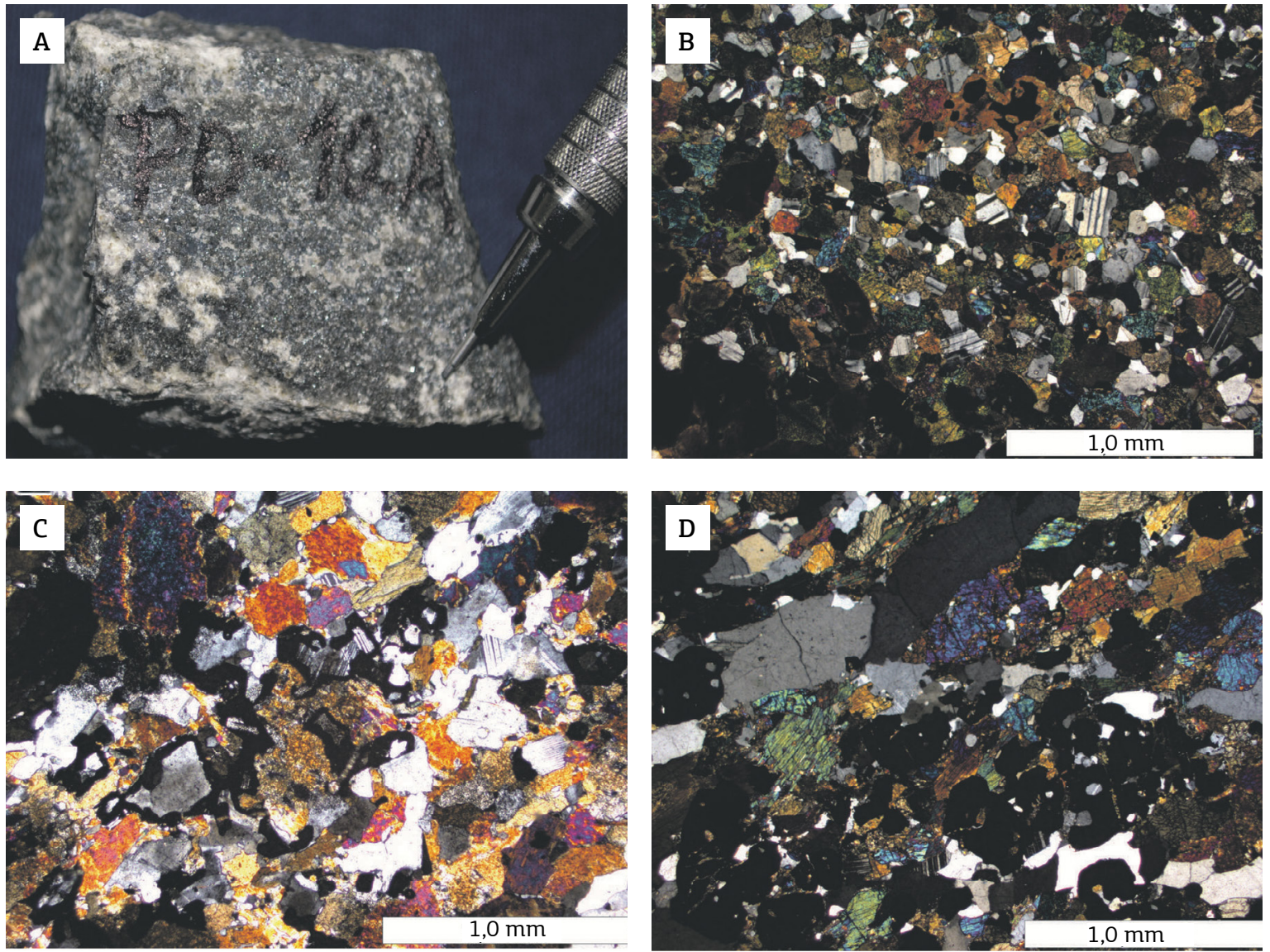

Figure 7. Petrographic aspects of the mafic granulites of Porangatu Granulite Complex: (A) isotropic finegrained granulite; (B) Polygonal granoblastic texture defined by plagioclase, orthopyroxene, clinopyroxene and hornblende; (C) Honeycomb-type garnet texture formed by reaction Pl $+\mathrm{Cpx}_{1}(\mathrm{Opx})=\mathrm{Grt}+\mathrm{Cpx}{ }_{2}+\mathrm{Qtz}$; (D) Garnet porphyroblasts rich in plagioclase and pyroxene inclusions. All photomicrographs under crossed polarizers. 
The amphibolites form narrow or lens-shaped bodies within the mylonitic zone, oriented parallel to the main structural trend of NNE-SSW. They are mainly exposed along the eastern and western margins of the mylonitic domain. Their dimensions vary from metres to tens of kilometres. The largest of such bodies are the Serra da Bocaina and Barreirinho Vermelho amphibolites (Fig. 2). The first constitutes an 18-km long body with width ranging between 900 and 2,000 m. The Barreirinho
Vermelho Amphibolite also comprises a lens-shaped body of approximately the same size and is also elongated parallel to the regional mylonitic foliation. Several other smaller bodies are also present in the gneissic-supracrustal domain. They present nematoblastic or granoblastic texture and are formed by hornblende, diopside, calcic plagioclase $\left(\mathrm{An}_{63-75}\right)$, minor amounts of titanite, biotite and quartz, and accessory apatite and opaque minerals (Fig. 8). Garnet amphibolites contain up
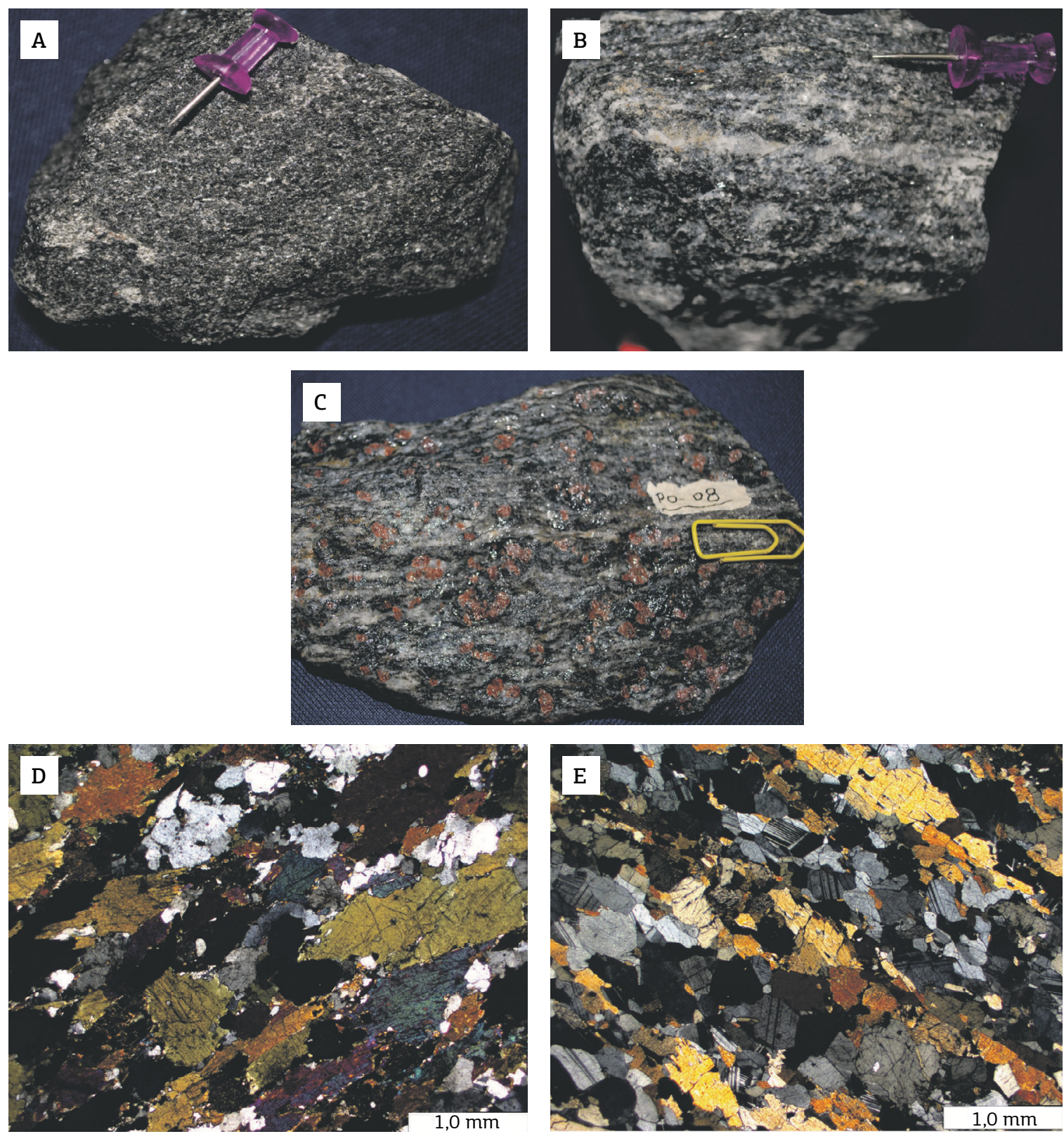

Figure 8. Petrographic aspects of the amphibolites of Porangatu Granulite Complex: (A) hornblende and plagioclase are oriented along the foliation; (B) Banded leucotonalitic leucosome (Pl-Qtz); (C) Garnet porphyroblasts in mylonitized amphibolite; (D) Nematoblastic texture marked by preferential orientation of hornblende and plagioclase; (E) Clinopyroxene amphibolite showing alteration of hornblende/clinopyroxene-rich bands with plagioclase-rich bands. All photo micrographs under crossed polarizers. 
to $40 \%$ modal garnet, accompanied by labradorite $\left(\mathrm{An}_{50-56}\right)$ and hornblende, and display porphyroblastic texture marked by ocellar garnet porphyroblasts. Coronitic textures are common, defined by garnet-clinopyroxene-quartz symplectites, which represent metamorphic reactions between plagioclase and clinopyroxene or hornblende. Amphibolites which do not contain garnet display a simple mineralogical association of calcic plagioclase, hornblende and titanite (up to $2 \%$ modal).

The metamorphic studies reveal that the Porangatu Complex comprises a high-grade metamorphic terrain that reached maximum metamorphic conditions in the granulite facies. Temperature and pressure above $850^{\circ} \mathrm{C}$ and $10 \mathrm{kbar}$ are suggested by the following mineral parageneses: Opx $+\mathrm{Cpx}+\mathrm{Qtz}+\mathrm{Ca}-\mathrm{Pl}$ Antip $\pm \mathrm{Mc}+\mathrm{Grt} \pm \mathrm{Bt}$ (felsic granulites, enderbites and charnockites); Opx $+\mathrm{Cpx}+\mathrm{Ca}-\mathrm{Pl}$ $\pm \mathrm{Hbl}+\mathrm{Grt}$ (mafic granulite); $\mathrm{Ca}-\mathrm{Pl}+\mathrm{Cpx}+\mathrm{Hbl} \pm \mathrm{Grt}$ \pm Ttn (amphibolites). Moreover, the occurrence of small charnockitic bodies and veins (patch and veinlet migmatite structures) isolated in enderbites and mafic granulites are indicative of anatectic processes at high-temperature in almost anhydrous environment.

\section{SHRIMP U-Pb Geochronology}

For geochronological studies, samples were collected from two outcrops of the granulite terrain to the west of Cajueiro Village (Fig. 2). Zircon concentrates were obtained by conventional gravimetric and magnetic methods at the Institute of Geosciences of the Federal University of Pará. SHIRIMP U-Pb geochronological analyses were carried out by ion microprobe at the Research School of Earth Sciences, Australian National University, Canberra. Analytical work followed the general procedures described by Williams \& Claesson (1987) and Compston et al. (1992). Concordia ages were calculated using Isoplot/Ex (http://www.bgc.org/ isoplot_etc/isoplot.html). Errors on ages reported in the figures and text are 2 sigma.

Two samples were selected for geochronology: a garnet mafic granulite and a charnockite. The latter represents small isolated bodies in garnet enderbite (see Fig. 6B), which are interpreted as anatectic melts formed at the climax of the granulite metamorphism.

Geochronological data for the mafic granulite (PO-07) are scattered (Tab. 1). Most analysed spots yield Paleoproterozoic ages between 1.8 and $2.2 \mathrm{Ga}$, although two spots give ${ }^{206} \mathrm{~Pb} /{ }^{238} \mathrm{U}$ ages of ca. 570 and $550 \mathrm{Ma}$, and another one, $485 \mathrm{Ma}$. The high Th/U ratios for all spots $(0.27-0.49)$ are typical of igneous zircon. In the Wetherill diagram (Fig. 9) the majority of the data fall around a Discordia with an upper intercept at $2092 \pm 16 \mathrm{Ma}$ and an imprecise lower intercept at $548 \pm 48 \mathrm{Ma}$, albeit with a high MSWD (4.1). This rough alignment suggests late Neoproterozoic Pb-loss from Paleoproterozoic zircon formed at ca. 2.1 Ga, which is taken as the crystallization age of the protolith. The Pb-loss event is thought to be the high-temperature metamorphism, the age of which is better constrained by results on the charnockite.

In case of the charnockite (sample PO-40C), most zircons (22) gave Early Cambrian and Neoproterozoic ${ }^{206} \mathrm{~Pb} /{ }^{238} \mathrm{U}$ ages between 516 and $630 \mathrm{Ma}$ (Table 2), with an upper intercept in the Wetherill concordia diagram at $583 \pm 15 \mathrm{Ma}$ (mean square of the weighted deviates MSWD = 1.17) (Fig. 10A). Two groups are distinguished: (i) high $\mathrm{Th} / \mathrm{U}(0.1$ - 1.0, i.e., igneous grains) and (ii) low $\mathrm{Th} / \mathrm{U}(0.01-0.04)$ metamorphic overgrowths that in cathodoluminescence images show as low luminescent rims around the igneous zircons, typical of metamorphic growth. Data for the first group (8 samples) give a Concordia age of $581 \pm 15 \mathrm{Ma}$ (Fig. 10B), of which 5 cluster at $567 \pm 12 \mathrm{Ma}$ (Fig. 10C). The ${ }^{206} \mathrm{~Pb} /{ }^{238} \mathrm{U}$ ages for the 14 low-Th/U zones range from 516 to $590 \mathrm{Ma}$, but the 9 most concordant of these give a Concordia age of $580 \pm 8 \mathrm{Ma}$ (Fig. 11). This is taken as clear evidence that the charnockite underwent high-T metamorphism at ca. $580 \mathrm{Ma}$, with possible slight $\mathrm{Pb}$ loss in some zircon. The age of the Neoproterozoic high $\mathrm{Th} / \mathrm{U}$ grains in this rock cannot be distinguished from that of metamorphism and they are interpreted as having formed during the generation of charnockite neosomes in enderbite at granulite facies conditions; the combined age of this event is $577 \pm 7 \mathrm{Ma}$.

There also are three older grains of 3.08, 1.96 and $0.88 \mathrm{Ga}\left({ }^{207} \mathrm{~Pb} /{ }^{206} \mathrm{~Pb}\right.$ ages) (Table 2$)$. The Archaean and Paleoproterozoic ages have records in the Goiás Massif, and the $0.88 \mathrm{Ga}$ inherited zircon grains are correlated with the Goiás Magmatic Arc.

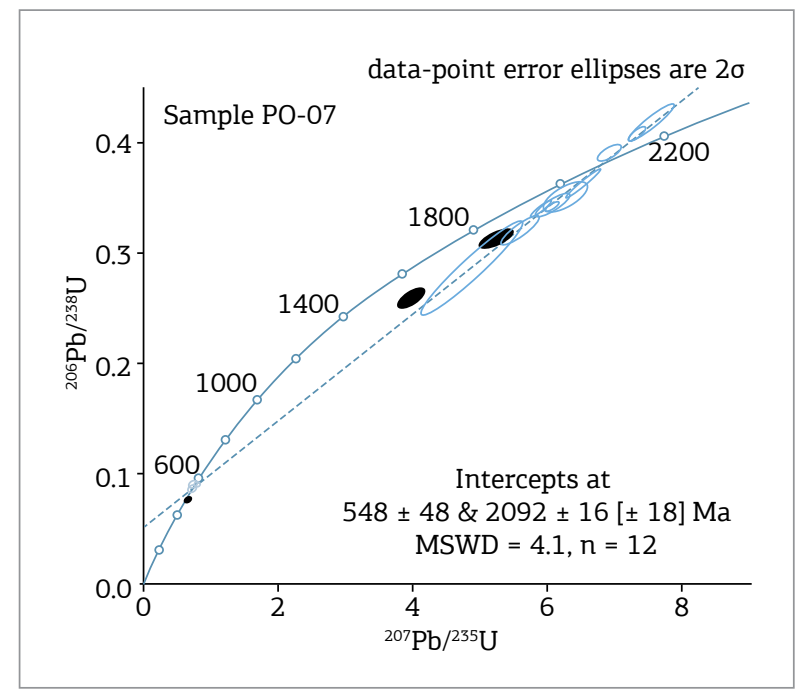

Figure 9. Zircon $\mathrm{U}-\mathrm{Pb}$ concordia diagram for sample PO-07 (mafic granulite), with data of Table 1. 
Table 1. Summary of SHRIMP U-Pb zircon data for sample PO-07.

\begin{tabular}{|c|c|c|c|c|c|c|c|c|c|c|c|c|}
\hline \multirow{3}{*}{\begin{tabular}{|l|} 
Zircon \\
Spot \\
\end{tabular}} & \multirow{3}{*}{$\begin{array}{c}\text { f206 } \\
(\%)\end{array}$} & \multirow{3}{*}{$\begin{array}{c}\text { U } \\
\text { ppm }\end{array}$} & \multirow{3}{*}{$\begin{array}{c}\mathrm{Pb} \\
\mathrm{ppm}\end{array}$} & \multirow{3}{*}{$\begin{array}{c}\text { Th } \\
\text { ppm }\end{array}$} & \multirow{3}{*}{$\mathrm{Th} / \mathrm{U}$} & \multicolumn{7}{|c|}{ Ratios ${ }^{\#}$} \\
\hline & & & & & & \multirow{2}{*}{${ }^{207} \mathrm{~Pb} /{ }^{235} \mathrm{U}$} & \multirow{2}{*}{$\begin{array}{l}\text { 1s } \\
(\%)\end{array}$} & \multirow{2}{*}{${ }^{206} \mathrm{~Pb} /{ }^{238} \mathrm{U}$} & \multirow{2}{*}{$\begin{array}{l}\text { 1s } \\
(\%)\end{array}$} & \multirow{2}{*}{ Rho } & \multirow{2}{*}{${ }^{207} \mathrm{~Pb} /{ }^{206} \mathrm{~Pb}$} & \multirow{2}{*}{$\begin{array}{l}\text { 1s } \\
(\%)\end{array}$} \\
\hline & & & & & & & & & & & & \\
\hline 1.1 & 0.05 & 115 & 39 & 38 & 0.34 & 6.91152 & 0.95 & 0.39176 & 0.74 & 0.78 & 0.12795 & 0.60 \\
\hline 1.2 * & 0.62 & 84 & 19 & 22 & 0.27 & 3.96548 & 2.00 & 0.26110 & 1.26 & 0.63 & 0.11015 & 1.55 \\
\hline 2.1 & 0.09 & 115 & 9 & 30 & 0.27 & 0.75867 & 4.22 & 0.09211 & 0.90 & 0.21 & 0.05973 & 4.12 \\
\hline 3.1 & 0.35 & 52 & 13 & 18 & 0.36 & 4.86480 & 6.43 & 0.28736 & 6.21 & 0.97 & 0.12278 & 1.68 \\
\hline $4.1^{*}$ & 0.00 & 212 & 57 & 75 & 0.37 & 5.23078 & 1.91 & 0.31427 & 1.13 & 0.59 & 0.12071 & 1.54 \\
\hline 5.1 & 0.05 & 258 & 91 & 123 & 0.49 & 7.34117 & 0.69 & 0.40912 & 0.59 & 0.86 & 0.13014 & 0.35 \\
\hline 6.1 & 0.06 & 331 & 97 & 108 & 0.34 & 5.88674 & 1.02 & 0.34065 & 0.95 & 0.93 & 0.12533 & 0.36 \\
\hline 7.1 & 0.05 & 372 & 110 & 177 & 0.49 & 6.07389 & 0.68 & 0.34250 & 0.56 & 0.82 & 0.12862 & 0.39 \\
\hline 8.1 & 0.09 & 148 & 53 & 60 & 0.42 & 7.53998 & 1.76 & 0.41932 & 1.68 & 0.95 & 0.13041 & 0.53 \\
\hline 9.1 & 0.14 & 112 & 34 & 38 & 0.35 & 6.24359 & 2.15 & 0.35222 & 1.53 & 0.71 & 0.12856 & 1.52 \\
\hline 10.1 & 0.07 & 246 & 19 & 98 & 0.41 & 0.71813 & 2.83 & 0.08853 & 1.61 & 0.57 & 0.05883 & 2.33 \\
\hline 10.2 * & 0.21 & 149 & 10 & 43 & 0.30 & 0.63423 & 3.32 & 0.07809 & 1.56 & 0.47 & 0.05890 & 2.93 \\
\hline 11.1 & 0.02 & 1245 & 369 & 324 & 0.27 & 6.06551 & 1.62 & 0.34482 & 1.43 & 0.88 & 0.12758 & 0.76 \\
\hline 11.2 & 0.02 & 1307 & 361 & 397 & 0.31 & 5.59211 & 2.12 & 0.32124 & 1.86 & 0.88 & 0.12625 & 1.01 \\
\hline 12.1 & 0.03 & 431 & 135 & 165 & 0.40 & 6.53532 & 1.45 & 0.36460 & 1.41 & 0.98 & 0.13000 & 0.30 \\
\hline
\end{tabular}

Table 1. Continuation.

\begin{tabular}{|c|c|c|c|c|c|c|c|}
\hline \multirow{3}{*}{$\begin{array}{l}\text { Zircon } \\
\text { Spot }\end{array}$} & \multicolumn{6}{|c|}{ Ages (Ma) } & \multirow{3}{*}{$\begin{array}{r}\text { Conc } \\
(\%)\end{array}$} \\
\hline & \multirow{2}{*}{${ }^{206} \mathrm{~Pb} /{ }^{238} \mathrm{U}$} & \multirow{2}{*}{$\begin{array}{c}\text { 1s } \\
\text { abs }\end{array}$} & \multirow{2}{*}{${ }^{207} \mathrm{~Pb} /{ }^{235} \mathrm{U}$} & \multirow{2}{*}{$\begin{array}{c}\text { 1s } \\
\text { abs }\end{array}$} & \multirow{2}{*}{${ }^{207} \mathrm{~Pb} /{ }^{206} \mathrm{~Pb}$} & $1 \mathrm{~s}$ & \\
\hline & & & & & & abs & \\
\hline 1.1 & 2131.0 & 15.7 & 2100.1 & 20.0 & 2070.0 & 12.5 & 101.5 \\
\hline $1.2^{*}$ & 1495.4 & 18.8 & 1627.2 & 32.5 & 1801.9 & 27.9 & 91.9 \\
\hline 2.1 & 568.0 & 5.1 & 573.2 & 24.2 & 594.0 & 24.5 & 99.1 \\
\hline 3.1 & 1628.3 & 101.1 & 1796.2 & 115.5 & 1997.1 & 33.5 & 90.7 \\
\hline 4.1 * & 1761.7 & 20.0 & 1857.6 & 35.5 & 1966.8 & 30.3 & 94.8 \\
\hline 5.1 & 2210.9 & 13.0 & 2153.8 & 14.8 & 2099.9 & 7.4 & 102.6 \\
\hline 6.1 & 1889.8 & 17.9 & 1959.3 & 19.9 & 2033.5 & 7.4 & 96.5 \\
\hline 7.1 & 1898.7 & 10.7 & 1986.5 & 13.6 & 2079.2 & 8.0 & 95.6 \\
\hline 8.1 & 2257.4 & 37.8 & 2177.8 & 38.3 & 2103.5 & 11.2 & 103.7 \\
\hline 9.1 & 1945.2 & 29.7 & 2010.6 & 43.3 & 2078.4 & 31.6 & 96.7 \\
\hline 10.1 & 546.8 & 8.8 & 549.6 & 15.6 & 561.0 & 13.1 & 99.5 \\
\hline 10.2 * & 484.7 & 7.5 & 498.7 & 16.6 & 563.5 & 16.5 & 97.2 \\
\hline 11.1 & 1909.8 & 27.2 & 1985.3 & 32.1 & 2064.9 & 15.7 & 96.2 \\
\hline 11.2 & 1795.8 & 33.4 & 1914.9 & 40.5 & 2046.4 & 20.7 & 93.8 \\
\hline 12.1 & 2004.0 & 28.3 & 2050.7 & 29.6 & 2098.0 & 6.3 & 97.7 \\
\hline
\end{tabular}

$f 206$ is the percentage of the common $\mathrm{Pb}$ found in ${ }^{206} \mathrm{~Pb}$, \# is the ratios corrected for common $\mathrm{Pb}$, *Zircons excluded from the calculation of age. Error in Standard calibration was $0.63 \%$ (not included in above errors but required when comparing data from different mounts).

Rho is the error correlation defined as the quotient of the propagated errors of the ${ }^{206} \mathrm{~Pb} /{ }^{238} \mathrm{U}$ and the ${ }^{207} \mathrm{~Pb} /{ }^{235} \mathrm{U} \mathrm{ratio}$.

Concordance.: Degree of concordance $=\left({ }^{206} \mathrm{~Pb} /{ }^{238} \mathrm{U} \text { age } /{ }^{207} \mathrm{~Pb} / 235 \mathrm{U} \text { age }\right)^{*} 100$. 
Paulo Sergio de Sousa Gorayeb et al.

Table 2. Summary of SHRIMP U-Pb zircon data for sample PO-40C distinguishing high Th/U and low Th/U.

\begin{tabular}{|c|c|c|c|c|c|c|c|c|c|c|c|c|}
\hline \multirow{3}{*}{$\begin{array}{l}\text { Zircon } \\
\text { Spot }\end{array}$} & \multirow{3}{*}{$\begin{array}{r}\text { f206 } \\
(\%) \\
\end{array}$} & \multirow{3}{*}{$\begin{array}{c}\mathrm{U} \\
\mathrm{ppm}\end{array}$} & \multirow{3}{*}{$\begin{array}{c}\mathrm{Pb} \\
\mathrm{ppm}\end{array}$} & \multirow{3}{*}{$\begin{array}{c}\text { Th } \\
\text { ppm }\end{array}$} & \multirow{3}{*}{$\mathrm{Th} / \mathrm{U}$} & \multicolumn{7}{|c|}{ Ratios $^{\#}$} \\
\hline & & & & & & \multirow{2}{*}{${ }^{207} \mathrm{~Pb} /{ }^{235} \mathrm{U}$} & \multirow{2}{*}{\begin{tabular}{|l|}
$1 s$ \\
$(\%)$
\end{tabular}} & \multirow{2}{*}{${ }^{206} \mathrm{~Pb} /{ }^{238} \mathrm{U}$} & \multirow{2}{*}{$\begin{array}{l}\text { 1s } \\
(\%)\end{array}$} & \multirow{2}{*}{ Rho } & \multirow{2}{*}{${ }^{207} \mathrm{~Pb} /{ }^{206} \mathrm{~Pb}$} & \multirow{2}{*}{$\begin{array}{l}\text { 1s } \\
(\%)\end{array}$} \\
\hline & & & & & & & & & & & & \\
\hline 1.1 & 0.27 & 426 & 38 & 86 & 0.20 & 0.83859 & 2.92 & 0.10350 & 2.67 & 0.92 & 0.05892 & 1.17 \\
\hline $2.2 \mathrm{c}$ & 0.01 & 236 & 18 & 156 & 0.66 & 0.72839 & 3.05 & 0.08863 & 2.72 & 0.89 & 0.05961 & 1.38 \\
\hline 7.1 & 0.23 & 615 & 52 & 169 & 0.27 & 0.81020 & 2.94 & 0.09809 & 2.67 & 0.91 & 0.06004 & 1.24 \\
\hline 8.2 * & 0.17 & 766 & 85 & 498 & 0.65 & 1.18506 & 2.80 & 0.12872 & 2.70 & 0.97 & 0.06688 & 0.73 \\
\hline $9.1 \mathrm{c}$ & 0.39 & 265 & 21 & 230 & 0.87 & 0.73486 & 3.74 & 0.09129 & 2.70 & 0.72 & 0.05861 & 2.59 \\
\hline $9.2 \mathrm{c}$ & 0.36 & 211 & 17 & 141 & 0.67 & 0.74935 & 3.52 & 0.09294 & 2.70 & 0.77 & 0.05869 & 2.25 \\
\hline $10.1^{*}$ & 0.11 & 116 & 48 & 77 & 0.66 & 15.44790 & 5.37 & 0.48086 & 4.65 & 0.87 & 0.23325 & 2.69 \\
\hline $10.2^{*}$ & 0.08 & 487 & 92 & 180 & 0.37 & 3.65378 & 2.74 & 0.22108 & 2.67 & 0.98 & 0.11996 & 0.57 \\
\hline $11.1 \mathrm{c}$ & 0.24 & 147 & 12 & 14 & 0.09 & 0.76112 & 3.52 & 0.09157 & 2.72 & 0.77 & 0.06043 & 2.23 \\
\hline 13.1 & 0.08 & 222 & 18 & 187 & 0.84 & 0.81900 & 3.62 & 0.09616 & 3.20 & 0.88 & 0.06182 & 1.68 \\
\hline $16.2 \mathrm{c}$ & 0.20 & 328 & 27 & 340 & 1.04 & 0.76837 & 2.95 & 0.09430 & 2.68 & 0.91 & 0.05921 & 1.23 \\
\hline 2.1 & 0.37 & 215 & 16 & 1 & 0.01 & 0.69955 & 4.81 & 0.08579 & 3.84 & 0.80 & 0.05936 & 2.89 \\
\hline $3.1 \mathrm{c}$ & 0.04 & 498 & 41 & 9 & 0.02 & 0.79422 & 2.84 & 0.09582 & 2.70 & 0.95 & 0.06013 & 0.86 \\
\hline $4.1 \mathrm{c}$ & 0.13 & 538 & 43 & 4 & 0.01 & 0.75297 & 2.91 & 0.09283 & 2.71 & 0.93 & 0.05890 & 1.06 \\
\hline 5.1 & 0.14 & 422 & 31 & 3 & 0.01 & 0.70267 & 3.05 & 0.08542 & 2.67 & 0.87 & 0.05974 & 1.48 \\
\hline $6.1 \mathrm{c}$ & 0.08 & 751 & 60 & 5 & 0.01 & 0.76500 & 2.75 & 0.09289 & 2.66 & 0.97 & 0.05978 & 0.72 \\
\hline 6.2 & 0.09 & 281 & 21 & 12 & 0.04 & 0.70103 & 3.05 & 0.08526 & 2.71 & 0.89 & 0.05969 & 1.39 \\
\hline $8.1 \mathrm{c}$ & 0.15 & 368 & 30 & 6 & 0.02 & 0.78585 & 2.94 & 0.09572 & 2.69 & 0.91 & 0.05963 & 1.20 \\
\hline $11.2 \mathrm{c}$ & 0.05 & 478 & 39 & 4 & 0.01 & 0.77155 & 2.85 & 0.09425 & 2.71 & 0.95 & 0.05940 & 0.87 \\
\hline 12.1 & 0.15 & 296 & 23 & 3 & 0.01 & 0.74167 & 2.92 & 0.08865 & 2.68 & 0.92 & 0.06076 & 1.16 \\
\hline 14.1 & 0.24 & 416 & 30 & 5 & 0.01 & 0.66730 & 2.87 & 0.08336 & 2.70 & 0.94 & 0.05820 & 0.98 \\
\hline $15.1 \mathrm{c}$ & 0.12 & 504 & 40 & 3 & 0.01 & 0.76411 & 2.83 & 0.09340 & 2.66 & 0.94 & 0.05940 & 0.96 \\
\hline $16.1 \mathrm{c}$ & 0.11 & 406 & 33 & 4 & 0.01 & 0.76594 & 2.87 & 0.09504 & 2.67 & 0.93 & 0.05852 & 1.05 \\
\hline $17.1 \mathrm{c}$ & 0.08 & 383 & 31 & 5 & 0.01 & 0.76125 & 2.91 & 0.09301 & 2.72 & 0.94 & 0.05940 & 1.03 \\
\hline $18.1 \mathrm{c}$ & 0.17 & 513 & 42 & 5 & 0.01 & 0.76623 & 2.88 & 0.09482 & 2.66 & 0.92 & 0.05871 & 1.10 \\
\hline
\end{tabular}


Table 2. Continuation.

\begin{tabular}{|c|c|c|c|c|c|c|c|}
\hline \multirow{3}{*}{$\begin{array}{l}\text { Zircon } \\
\text { Spot }\end{array}$} & \multicolumn{6}{|c|}{ Ages (Ma) } & \multirow{3}{*}{$\begin{array}{r}\text { Conc } \\
(\%)\end{array}$} \\
\hline & \multirow{2}{*}{${ }^{206} \mathrm{~Pb} /{ }^{238} \mathrm{U}$} & \multirow{2}{*}{$\begin{array}{c}\text { 1s } \\
\text { abs }\end{array}$} & \multirow{2}{*}{${ }^{207} \mathrm{~Pb} /{ }^{235} \mathrm{U}$} & \multirow{2}{*}{$\begin{array}{c}\text { 1s } \\
\text { abs }\end{array}$} & \multirow{2}{*}{${ }^{207} \mathrm{~Pb} /{ }^{206} \mathrm{~Pb}$} & $1 \mathrm{~s}$ & \\
\hline & & & & & & abs & \\
\hline 1.1 & 634.9 & 16.9 & 618.4 & 18.0 & 564.1 & 6.6 & 102.7 \\
\hline $2.2 \mathrm{c}$ & 547.5 & 14.9 & 555.6 & 17.0 & 589.4 & 8.1 & 98.5 \\
\hline 7.1 & 603.2 & 16.1 & 602.6 & 17.7 & 605.1 & 7.5 & 100.1 \\
\hline $8.2^{*}$ & 780.6 & 21.1 & 793.7 & 22.2 & 834.1 & 6.1 & 98.4 \\
\hline $9.1 \mathrm{c}$ & 563.2 & 15.2 & 559.4 & 20.9 & 552.6 & 14.3 & 100.7 \\
\hline $9.2 \mathrm{c}$ & 572.9 & 15.5 & 567.8 & 20.0 & 555.5 & 12.5 & 100.9 \\
\hline 10.1 * & 2531.0 & 117.7 & 2843.3 & 152.8 & 3074.5 & 82.7 & 89.0 \\
\hline 10.2 * & 1287.6 & 34.4 & 1561.3 & 42.7 & 1955.7 & 11.2 & 82.5 \\
\hline $11.1 \mathrm{c}$ & 564.8 & 15.3 & 574.7 & 20.2 & 619.1 & 13.8 & 98.3 \\
\hline 13.1 & 591.9 & 18.9 & 607.5 & 22.0 & 668.0 & 11.2 & 97.4 \\
\hline $16.2 \mathrm{c}$ & 580.9 & 15.6 & 578.8 & 17.1 & 575.0 & 7.1 & 100.4 \\
\hline 2.1 & 530.6 & 20.4 & 538.5 & 25.9 & 580.3 & 16.8 & 98.5 \\
\hline $3.1 \mathrm{c}$ & 589.9 & 16.0 & 593.6 & 16.8 & 608.4 & 5.2 & 99.4 \\
\hline $4.1 \mathrm{c}$ & 572.2 & 15.5 & 569.9 & 16.6 & 563.6 & 6.0 & 100.4 \\
\hline 5.1 & 528.4 & 14.1 & 540.4 & 16.5 & 594.2 & 8.8 & 97.8 \\
\hline $6.1 \mathrm{c}$ & 572.6 & 15.2 & 576.9 & 15.9 & 595.5 & 4.3 & 99.3 \\
\hline 6.2 & 527.4 & 14.3 & 539.4 & 16.4 & 592.3 & 8.2 & 97.8 \\
\hline $8.1 \mathrm{c}$ & 589.3 & 15.8 & 588.8 & 17.3 & 590.2 & 7.1 & 100.1 \\
\hline $11.2 \mathrm{c}$ & 580.6 & 15.7 & 580.7 & 16.5 & 581.8 & 5.0 & 100.0 \\
\hline 12.1 & 547.6 & 14.7 & 563.4 & 16.5 & 630.9 & 7.3 & 97.2 \\
\hline 14.1 & 516.2 & 13.9 & 519.1 & 14.9 & 537.2 & 5.3 & 99.4 \\
\hline $15.1 \mathrm{c}$ & 575.6 & 15.3 & 576.4 & 16.3 & 581.8 & 5.6 & 99.9 \\
\hline $16.1 \mathrm{c}$ & 585.3 & 15.6 & 577.4 & 16.6 & 549.1 & 5.8 & 101.4 \\
\hline $17.1 \mathrm{c}$ & 573.3 & 15.6 & 574.7 & 16.7 & 581.9 & 6.0 & 99.8 \\
\hline $18.1 \mathrm{c}$ & 584.0 & 15.6 & 577.6 & 16.6 & 556.3 & 6.1 & 101.1 \\
\hline
\end{tabular}

$f 206$ is the percentage of the common $\mathrm{Pb}$ found in ${ }^{206} \mathrm{~Pb}$, \# is the ratios corrected for common $\mathrm{Pb}$, *Zircons excluded from the calculation of age. Error in Standard calibration was $0.85 \%$ (not included in above errors but required when comparing data from different mounts).

Rho is the error correlation defined as the quotient of the propagated errors of the ${ }^{206} \mathrm{~Pb} / 238 \mathrm{U}$ and the ${ }^{207} \mathrm{~Pb} /{ }^{235} \mathrm{U}$ ratio.

Concordance: Degree of concordance $=\left({ }^{206} \mathrm{~Pb} /{ }^{238} \mathrm{U} \text { age } /{ }^{207} \mathrm{~Pb} /{ }^{235} \mathrm{U} \text { age }\right)^{*} 100, \mathrm{c}=$ Concordia Age

\section{CONCLUDING REMARKS}

Geological mapping, structural data combined with petrographic and geochronological studies using the SHRIMP U-Pb technique of high-grade metamorphic rocks of the Porangatu Granulite Complex indicate the presence of Archaean and Paleoproterozoic continental crustal material, which was strongly reworked during Brasiliano orogeny. The field and structural data reveal the presence of Neoproterozoic granulitic rocks preserved within the wide, ductile, high-temperature NNE-SSW Talismã Shear Zone (TSZ), flanked to the east by older gneiss terrains. The granulite rocks are juxtaposed with medium-high grade mylonitic gneisses, representing a mixture of lower and middle crustal rocks.

The SHRIMP U-Pb geochronological data indicate that the protoliths of mafic granulite are Paleoproterozoic (ca. 2.1 Ga) which were metamorphosed under high-grade conditions at 500-600 Ma, as indicated by an imprecise lower intercept 
age. The high-grade metamorphism also caused anatexis resulting in charnockite derived from enderbite gneiss. U-Pb ages for anatectic igneous zircon and metamorphic zircon are indistinguishable within the limits of their combined age of $580 \pm 7 \mathrm{Ma}$. These Neoproterozoic ages for the granulite

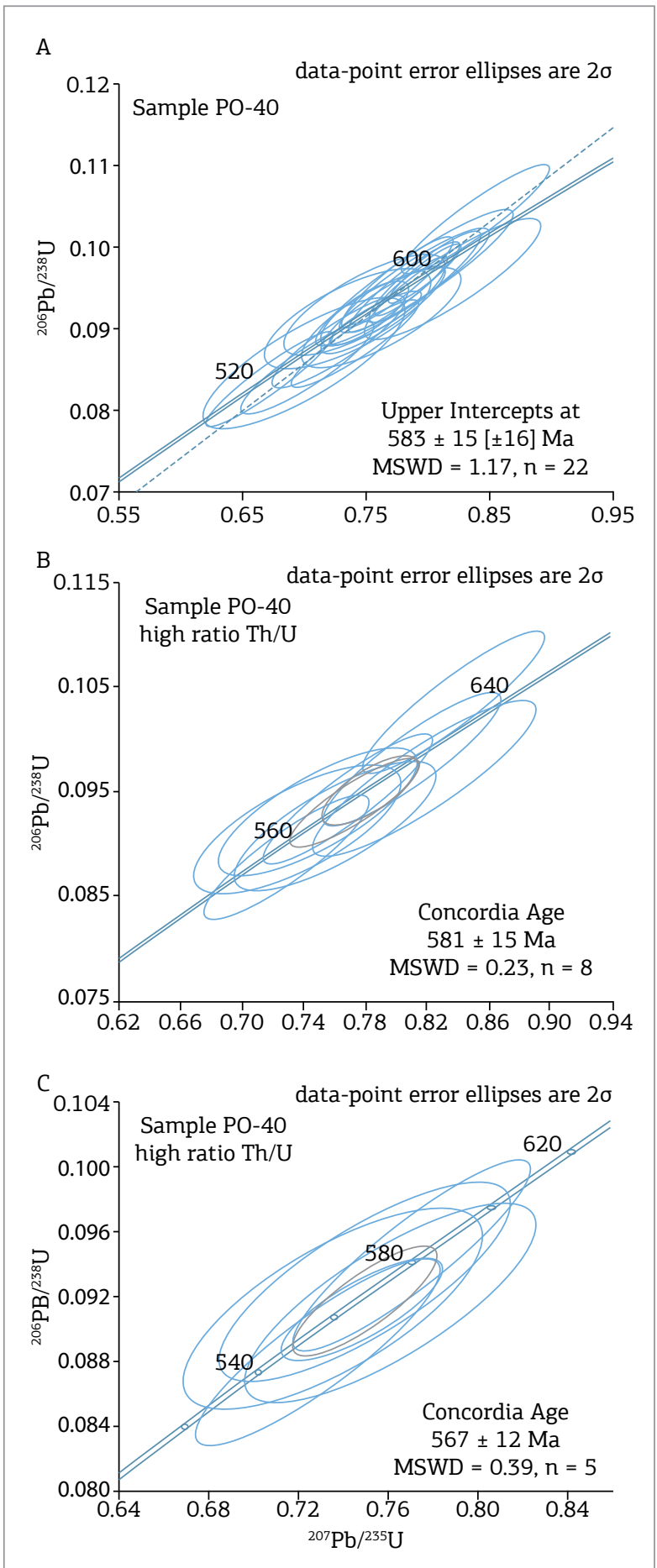

Figure 10. $\mathrm{U}-\mathrm{Pb}$ concordia diagram for zircon grains sample PO-40C (neossome charnockite) of Table 2: (A) All zircon grain; (B) High Th/U for eight zircon grains; (C) High Th/U for five zircon grains. metamorphism are smaller than those reported for other granulites (ca. 0.65 Ga) within the Brasília Belt, suggesting that the evolution of the Porangatu Granulite Complex is more likely associated with the evolution of the younger Araguaia Belt, and suggests that the final closure of the Araguaia ocean separating the Amazonian and São Francisco-Congo Craton took place later than previously suggested.

The structural data for this region suggest a collisional setting initiated by oblique thrusts followed by a dextral strike-slip system (TSZ), which is part of the transcontinental Transbrasiliano-Kandi Lineament. It is likely, however, that the initial deformational features involved important thrust components, responsible for the exhumation of rocks of the lower crust such as large lenses of infracrustal granulites $(>30 \mathrm{~km})$ with several elongated amphibolite and anatetic granitoid bodies, all emplaced at the same crustal level as the old gneiss-migmatite terrains. The granulites are juxtaposed with mylonitic gneisses, representing an important tectonic mixture of rock units of different crustal levels and ages (Archean, Paleoproterozoic, Neoproterozoic). The data suggest that charnockite PO-40C was emplaced at deep crustal levels and, therefore, igneous and metamorphic zircon crystals show essentially the same age $(0.57-0.59 \mathrm{Ga})$. Inherited Archaean and Paleoproterozoic zircon grains indicate the presence of older crustal material, as recorded in the Goiás Massif and Goiás Magmatic Arc.

Two relevant observations should be investigated in the future:

1. granulites and other metamorphic rocks, just to the west of the Serra Azul-Cajueiro Lineament, indicate younger high-grade metamorphic ages compared to the general pattern of Neoproterozoic granulites in other areas of

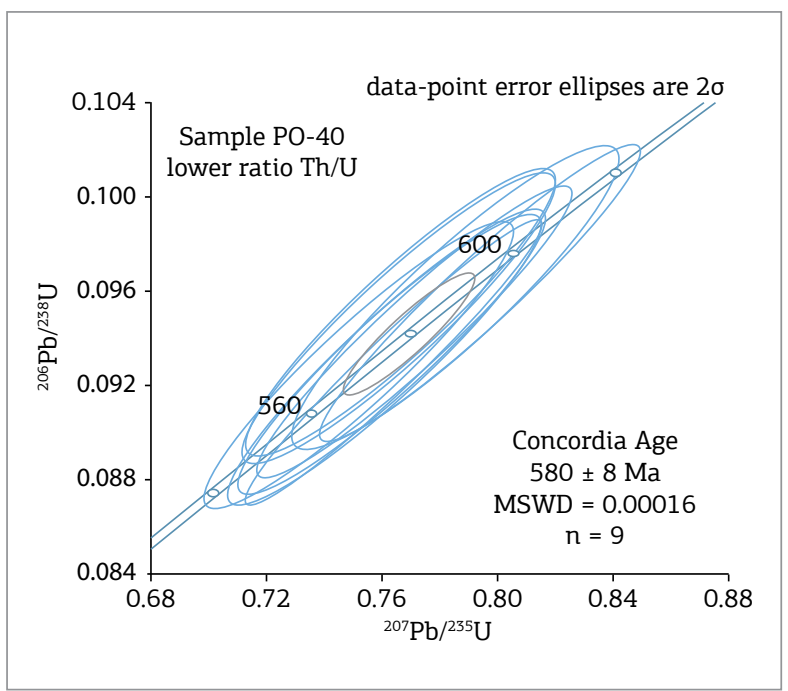

Figure 11. U-Pb concordia diagram for a selection of the most concordant low $\mathrm{Th} / \mathrm{U}$ zircon grains from sample PO-40C (charnockite). 
the Brasilia Belt; for instance, granulites of the Uruaçu and Anápolis-Itauçu complexes have metamorphic zircon ages between ca. $0.65-0.63 \mathrm{Ga}$, approximately $60 \mathrm{Ma}$ older than the Porangatu granulites; and

2. young high-grade rocks are identified in other areas along the TBL, for example granulitic rocks of Porto Nacional Complex associated with the Carreira Comprida Anorthosite further to the north, which yielded igneous age of ca. $0.53 \mathrm{Ga}$ (Lima et al. 2008), and granitic orthogneisses in the region of Sáo Miguel do Araguaia to the south, with $\mathrm{U}-\mathrm{Pb}$ ages of ca. $0.57-0.53 \mathrm{Ga}$ (Dantas et al. 2006, 2007).

These two observations probably mean that the high-grade rocks exposed roughly along the Transbrasiliano Lineament (TBL) may be related to late Neoproterozoic or even early Cambrian tectonic events along this shear zone, an event that is most likely related to the evolution of the Araguaia Belt, rather than to the Brasília Belt.

The metamorphic studies reveal that the Porangatu Complex comprises a high-grade metamorphic terrain which reached maximum metamorphic conditions in granulite facies, with temperatures above $850^{\circ} \mathrm{C}$ and a pressure greater than $10 \mathrm{kbar}$. This condition is suggested by the parageneses $\mathrm{Opx}+$ $\mathrm{Cpx}+\mathrm{Qtz}+\mathrm{Ca}-\mathrm{Pl}$ Antip $\pm \mathrm{Mc}+\mathrm{Grt} \pm \mathrm{Bt}$ (felsic granulites, enderbites and charnockites); $\mathrm{Opx}+\mathrm{Cpx}+\mathrm{Ca}-\mathrm{Pl}+\mathrm{Hbl}+\mathrm{Grt}$ (mafic granulite); $\mathrm{Ca}-\mathrm{Pl}+\mathrm{Cpx}+\mathrm{Hbl} \pm \mathrm{Grt} \pm \mathrm{Ttn}$ (amphibolites). Moreover, small bodies of charnockitic neosomes within the enderbitic and mafic granulites are the products of in situ anatexis during high-grade metamorphism in an anhydrous environment. Published data and those reported here indicate that the TBL is a high-grade ductile shear-zone superimposed and clearly discordant to the Brasilia Belt and that its age is ca. 570-580 Ma, i.e., Late Neoproterozoic.

Along the TBL from the center of Tocantins State as far as the northwest of Ceará are mega-lenses of granulitic rocks representing slices of the lower crust in the aligned NNESSW direction. The main representatives are the granulitic complexes of Porangatu, Porto Nacional, Granja, Cariré and Macaco (Gorayeb 1996a, Gorayeb \& Abreu 1998, Gorayeb et al. 2000, Amaral et al., 2012, Praxedes et al. 2012). These bodies are closely associated with high temperature ductile shear zones in several branches of the TBL and record of the initial stages of the continental collision, which led to the exhumation of infracrustal rocks at the end of the Neoproterozoic. In spite of the great distances between these granulitic bodies, the common point in addition to the reworking in shear zones is the similarity in the age of the high-grade metamorphism in the Neoproterozoic (Granja - $572 \pm 32 \mathrm{Ma}$; Cariré - ca. $589 \mathrm{Ma}$ ) on Paleoproterozoic protolith, which are coincident with the ages of Porangatu. The age of the TBL is still imprecise, and requires specific studies in the high-temperature mylonite zones. However, anorogenic granitic plutons from the Lageado suite dated between 552 and $545 \mathrm{Ma}$ (Gorayeb et al. 2013) cut the granulitic rocks and TBL structures, at the end of the Neoproterozoic. Emplacement of these plutons is related to an extensional tectonic system representing reactivation of this lineament. This makes it possible to bracket the formation of the TBL between approximately 550 and $580 \mathrm{Ma}$.

We may compare the geological data of the granulitic rocks of Porangatu with those of Porto Nacional to the north (Gorayeb et al. 2000), and the Cariré Granulite Belt in northwestern Ceará (Gorayeb \& Abreu 1989, Santos et al. 2008a, 2008b). The structural and geochronological characteristics are very similar and reveal an intimate association with TBL, which can be interpreted as representing lower portions (roots) of the Tocantins Orogen at 570 - $580 \mathrm{Ma}$. The data presented here are significant for the evolutionary understanding of the Brasiliano system, and consequently of the geology of central Brazil, and even for West Gondwana amalgamation.

\section{ACKNOWLEDGEMENT}

The present study was funded by Geosciences Institute of the Amazonia Project - GEOCIAM/INCT, process number 573733/2008-2 (CNPq/MCT/FAPESPA), with additional support from the Post-Graduate Program in Geology and Geochemistry of the Federal University of Pará, and the Geochronology Laboratories of the University of Brasília and of the Australian National University. We are very grateful to the reviewers, and to the associate editor Dr. Bob Pankhurst for their criticisms and suggestions, which led to the improvement of this work.

\section{REFERENCES}

Almeida, F.F.M. 1984. Província Tocantins-setor sudoeste. In: Almeida, F.F.M. \& Hasui Y. (eds.). O Pré-Cambriano do Brasil. Blücher, São Paulo, p.265-281.

Almeida F.F.M., Brito-Neves B.B., Hasui Y. 1981. Brazilian structural provinces: an introduction. Earth-Science Reviews, 17:1-29.
Alvarenga C.J.S., Moura C.A.V., Gorayeb P.S.S., Abreu F.A.M. 2000. Paraguay and Araguaia belts. In: Cordani U.G., Milani E.J., Filho A.T., Campos D.A. (eds.). Tectonic evolution of South America. Rio de Janeiro, $31^{\text {st }}$ International Geological Congress, p.183-193. 
Alvarenga C.J.S., Trompette R. 1993. Evolução tectônica brasiliana da Faixa Paraguai: a estruturação da região de Cuiabá. Revista Brasileira de Geociências, 23:18-30.

Amaral W.S., Santos T.J.S., Wernick E., Nogueira Neto, J.A. Dantas E.L., Matteini M. 2012. High-pressure granulites from Cariré, Borborema Province, NE Brazil: Tectonic setting, metamorphic conditions and U-Pb, Lu-Hf and Sm-Nd geochronology. Gondwana Research, 22:892-909.

Araujo C.E.G., Weinberg R.F., Cordani U.G. 2014. Extruding the Borborema Province (NE-Brazil): a two-stage Neoproterozoic collision process. Terra Nova, 26:157-168.

Arthaud M.H., Caby R., Fuck R.A., Dantas E.L., Parente C.V. 2008. Geology of the northern Borborema Province, NE Brazil and its correlation with Nigeria, NW Africa. In: Pankhurst R.J., Trouw R.A.J., Brito Neves B.B., De Wit M.J. (eds.). West Gondwana: Pre-Cenozoic correlations across the Atlantic region. Geological Society, 294:49-67.

Attoh K., Brown L.D. 2008. The Neoproterozoic Trans-Saharan/ Trans-Brasiliano shear zones: suggested Tibetan analogs. American Geophysical Union, Spring Meeting (abstract \#S51A-04).

Bard J.P. 1980. Microtextures of igneous and metamorphic rocks. Springer, Netherlands, 264p.

Barros L.D. 2015. Caracterização geológica da Suíte Ofiolítica Serra do Tapa, SE do Pará - Cinturão Araguaia. Dissertação de Mestrado, Universidade Federal do Pará, Belém, 97p.

Best M.G. 1982. Igneous and Metamorphic Petrology. W.H. Freeman, San Francisco, 630p.

Boggiani P.C., Gaucher C., Sial A.N.; Babinski M., Simon C.M. Riccomini C., Ferreira V.P., Fairchild T.R. 2010. Chemostratigraphy of the Tamengo Formation (Corumbá Group, Brazil): a contribution to the calibration of the Ediacaran carbon-isotope curve. Precambrian Research, 182:382-401.

Brito-Neves B.B., Fuck R.F., Pimentel M.M. 2014. The Brasiliano collage in South America: a review. Brazilian Journal of Geology, 44:493-518

Caby R. 2003. Terrane assembly and geodynamic evolution of central western Hoggar: a synthesis. Journal of African Earth Sciences, 37:133-159.

Cacama M.S.J.B., Sá E.F.J., Lins F.A.P.L. 2015. Assinatura estrutural e geofísica da porção norte (fronteira Ceará-Piauí) do Lineamento Transbrasiliano: reativação na Bacia do Parnaíba. Geologia USP, 15:3-4.

Cavalcante J.C., Vasconcelos A.M., Medeiros M.F., Paiva I.P., Gomes F.E.M., Cavalcante S.N., Cavalcante J.E., Melo A.C.R., Duarte Neto V.C., Bevenides H.C. 2003. Mapa Geológico do Estado do Ceará. Escala 1:500.000. Fortaleza, CPRM - Serviço Geológico do Brasil.

Compston W., Williams I.S., Kirschvink J.L., Zhang Z., Ma G. 1992. Zircon U-Pb ages for the early Cambrian timescale. Journal of the Geological Society of London, 149:171-184

Cordani U.G., Pimentel M.M., Araújo C.E.G., Fuck R.A. 2013. The significance of the Transbrasiliano-Kandi tectonic corridor for the amalgamation of West Gondwana. Brazilian Journal of Geology, 43:583-597.

Dantas E.L., Araujo Filho J.O., Oliveira C.G., Chiarini M.F.N., Fuck R.A., Sordi D.A. 2007. Nota explicativa da Folha Porangatu (SD.22-X-D-I). Escala 1:100.000. UnB/CPRM, Goiás, 59p.

Dantas E.L., Araujo Filho J.O., Oliveira C.G., Fuck R.A., Pimentel M.M., Chiarini M.F.N. 2006. Isótopos de $\mathrm{Nd}$ na determinação de blocos crustais na região de Porangatu-GO. In: SBG - Congresso Brasileiro de Geologia, 43, Aracaju. Anais, v.1, p.127.

Dardenne M.A. 2000. The Brasilia Fold Belt. In: Cordani U.G.; Milani E.J.;Thomaz Filho A.; Campos D.A. (Orgs.). Tectonic Evolution of South America. CRPM, Rio de Janeiro. p.231-263.
De Waard D. 1965. The occurrence of garnet in the granulite facies terrene of the Adirondack Highlands. Journal of Petrology, 6:165-191.

Ferreira Filho C.F., Pimentel M.M., Araújo S.M., Laux J.H. 2010. Layered intrusions and volcanic sequences in central Brazil: geological and geochronological constraints for Mesoproterozoic $(1.25 \mathrm{Ga})$ and Neoproterozoic $(0.79 \mathrm{Ga})$ igneous associations. Precambrian Research, 183:617-634

Fischel D.P, Pimentel M.M., Fuck R.A. 1998. Idade do metamorfismo de alto grau no Complexo Anápolis-Itauçu, Goiás, determinada pelo método Sm-Nd. Revista Brasileira de Geociências, 28:543-544.

Fuck R.A. Sá E.F.J., Pimentel M.M., Dardenne M.A., Soares A.C.P. 1993. As faixas de dobramentos marginais do Cráton do São Francisco; síntese dos conhecimentos. In: Dominguez J.M.L., Misi A. (Orgs.). O Cráton do São Francisco. SBG-SGM-CNPq, Salvador, v.1, p.161-185.

Gama Jr. T., Gorayeb P.S.S., Abreu F.A.M. 1988. O Granito Pedra do Sal e suas feições de cisalhamento. Revista Brasileira de Geociências, 18:424-432.

Giustina M.E.D, Pimentel M.M., Ferreira Filho C.F., Hollanda M.H.B.M. 2011. Dating coeval mafic magmatism and ultrahigh temperature metamorphism in the Anápolis-Itauçu Complex, Central Brazil. Lithos, 124:82-102.

Gorayeb P.S.S. 1996a. A Faixa Granulítica de Porangatu: caracterização litoestrutural e tectono-metamórfica. In: Congresso Brasileiro de Geologia, 39, Salvador. Anais, p.303-305.

Gorayeb P.S.S. 1996b. Petrologia e evolução crustal das rochas de alto grau de Porto Nacional-TO. Tese de Doutorado, Universidade Federal do Pará, 262 p.

Gorayeb P.S.S., Abreu F.A.M. 1989. A Faixa de Alto Grau de Cariré. In Simpósio de Geologia do Nordeste, 13, Fortaleza. Atas, p.182-184.

Gorayeb P.S.S., Abreu, F.A.M. 1998. Granulito Macaco: nova ocorrência de rochas granulíticas na Província Borborema. In: Congresso Brasileiro de Geologia, 40, Belo Horizonte. Anais, p.472-472.

Gorayeb P.S.S., Chaves C.L., Moura C.A.V., Lobo L.R.S. 2013. Neoproterozoic granites of the Lajeado intrusive suite, north-center Brazil: a late Ediacaran remelting of a Paleoproterozoic crust. Journal of South American Earth Sciences, 45:278-292.

Gorayeb P.S.S., Lima A.M.M. 2014. Aspectos texturais do magmatismo e tramas da tectônica impostas ao Granito Chaval na Zona de Cisalhamento Santa Rosa, extremo noroeste da Província Borborema. Brazilian Journal of Geology, 44:653-668.

Gorayeb P.S.S., Moura C.A.V., Abreu F.A.M. 2008. Geologia do Parque Andorinhas e região adjacente. In: Gorayeb P.S.S. (ed.). Parque Martírios-Andorinhas: história, conhecimento e preservação. UDUFPA, Belém, p.21-35.

Gorayeb P.S.S., Moura C.A.V., Barros G.R. 2000. Pb-Pb zircon ages of the Porto Nacional high-grade metamorphic terrain, northern portion of the Goiás Massif, Central Brazil. Revista Brasileira de Geociências, 30:190-194.

Harley L.S. 1985. Garnet-orthopiroxene bearing granulites from Enderby Land, Antarctica: metamorphic pressure-temperaturetime evolution of the Archean Napier Complex. Journal of Petrology, 26:819-856

Jost H., Chemale Jr. F., Fuck R.A., Dussin I. 2013. Uvá Complex, the oldest orthogneisses of the Archean-Paleoproterozoic terrane of Central Brazil. Journal of South American Earth Sciences, 47:201-212

Kotschoubey B., Hieronymus B., Albuquerque C.A.R. 2005. Disrupted peridotites and basalts from the Neoproterozoic Araguaia Belt (northern Brazil): remnants of a poorly evolved crust? Journal of South American of Earth Science, 20:211-230. 
Kroener A., Cordani U.G. 2003. African, southern Indian and South American cratons were not part of the Rodinia supercontinent: evidence from field relationships and geochronology. Tectonophysics, 375:325-352.

Laux J.H. 2004. Evolução do Arco Magmático de Goiás com base em dados geocronológicos $\mathrm{U}-\mathrm{Pb}$ e Sm-Nd. Tese de Doutorado, Universidade de Brasília, Brasília.

Laux J.H., Pimentel M.M., Dantas E.L., Armstrong R.A., Junges S.L. 2005. Neoproterozoic crustal accretion events in the Brasília belt, central Brazil. Journal of South American Earth Sciences, 18:183-198.

Lima H.A., Ferreira Filho C.F., Pimentel M.M., Dantas E.L., Araujo S.M. 2008. Geology, petrology and geochronology of the layered maficultramafic intrusions in the Porto Nacional area, central Brazil. Journal of South American Earth Sciences, 26:300-317.

Machado E.C., Moreton L.C., Pinheiro M.M. 1981. Projeto Porangatu: relatório final, etapa II. DNPM/CPRM, Goiânia, v. 1, 246p.

McGee B., Collins A.S., Trindade R.I.F. 2012. G'day Gondwana - the final accretion of a supercontinent. U-Pb ages form the post-orogenic São Vicente granite, Northern Paraguay belt, Brazil. Gondwana Research, 21:316-322.

Miyagawa L.JPP., Gorayeb P.S.S. 2013. Basaltos almofadados da Suíte Ofiolítica Morro do Agostinho: registros de fundo oceânico na porção centro-oeste do Cinturão Araguaia. Geologia USP, 13:111-124.

Moura C.A.V., Pinheiro B.L.S., Nogueira A.C.R., Gorayeb P.S.S., GalarzaToro M.A. 2008. Sedimentary provenance and palaeoenvironment of the Baixo Araguaia Supergroup: constraints on the palaeogeographical evolution of the Araguaia Belt and assembly of West Gondwana. In: Pankhurst R.J., Trouw R.A.J., Brito-Neves B.B., De Wit M.J. (Eds.). West Gondwana: pre-Cenozoic correlations across the South Atlantic region. Geological Society of London, 294:173-196.

Oliveira D.C., Mohiak W.U. 2003. Jaibaras through: an important element in the early tectonic evolution of the Parnaíba interior sab basin, northern Brazil. Marine and Petroleum Geology, 20:351-383.

Paixão M.R.P, Gorayeb P.S.S. 2014. Metalogênese do Cinturão Araguaia. In: Silva M.G, Rocha Neto M.B., Jost H., Kuyumijian R.M. (Orgs.). Metalogênese das províncias tectônicas brasileiras. Belo Horizonte, CPRM, p. 467-488.

Paixão M.R.P., Nilson A.A., Dantas E.L. 2008. The mesoproterozoic Quatipuru ophiolite and the Araguaia fold belt, central-northern Brazil. In: Pankhurst R.J., Trouw R.A.J., Brito-Neves B.B., De Wit M.J. (Eds.). West Gondwana Pre-Cenozoic Correlations Across the South Atlantic Region. Geological Society of London, 294:297-318.

Pimentel M. M., Fuck R. A. 1992. Neoproterozoic crustal accretion in central Brazil. Geology, 20:375-379.

Pimentel M.M., Fuck R.A, Gioia S.M. 2000. The Neoproterozoic Goiás Magmatic Arc: a review and new Sm-Nd isotopic data. Revista Brasileira de Geociências, 30:35-39.

Pimentel M.M., Heaman L., Fuck R.A, Marini O.J. 1991. U-Pb zircon geochronology of Precambrian tin-bearing continental-type acid magmatism in central Brazil. Precambrian Research, 52:321-335.
Pimentel M.M., Rodrigues J.B., Giustina M.E.D, Junges S.L., Matteini M., Armstrong R.A. 2011. The tectonic evolution of the Neoproterozoic Brasília Belt, central Brazil, based on SHRIMP and LA-ICPMS U-Pb sedimentary provenance data: a review. Journal of South American Earth Sciences, 31:345-357.

Pimentel M.M., Whitehouse M.J., Viana M.G., Fuck R.A, Machado N. 1997. The Mara Rosa arc in the Tocantins Province: further evidence for neoproterozoic crustal accretion in central Brazil. Precambrian Research, 81:299-310.

Piuzana D., Pimentel M.M., Fuck R.A., Armstrong R. 2003. Neoproterozoic granulite facies metamorphism and coeval granitic magmatism in the Brasilia Belt, Central Brazil: regional implications of new SHRIMP U$\mathrm{Pb}$ and Sm-Nd data. Precambrian Research, 125:245-273.

Praxedes I.F., Silva A.J.F., Soares W.C., Magini C., Azevedo M.R., Nogueira Neto J.A., Fuck R.A. 2012. Idade de anatexia no Complexo de Granja, Domínio Médio Coreaú, Província Borborema. In: SBG, Congresso Brasileiro de Geologia, 46; Congresso de Geologia dos Países de Língua Portuguesa, 1. Anais, CD-ROM.

Ribbe P.H. 1983. Feldspar mineralogy (Reviews in Mineralogy). Mineralogical Society of America, 2:362p

Santos R.D., Castro D.L., Bezerra H.R., Vidotti R.M., Fuck R.A., Dantas E.L., Lima T.P.C. 2013. Influência do Lineamento Transbrasiliano na formação do arcabouço estrutural da Bacia do Parnaíba. In: International Congress of the Brazilian Geophysical Society, 13. Anais, p.1-6.

Santos T.J.S., Fetter A.H., Hackspacher P.C., Van Schmus W.R., Nogueira Neto J.A. 2008a. Neoproterozoic tectonic and magmatic episodes in the NW sector of Borborema Province, NE Brazil, during assembly of Western Gondwana. Journal of South American Earth Sciences, 25:271-284.

Santos T.J.S., Fetter A.H., Nogueira Neto J.A. 2008b. Comparisons between the northwestern Borborema Province, NE Brazil, and the southwestern Pharusian Dahomey Belt, SW Central Africa. In: Pankhurst R.J., Trouw R.A.J., Brito Neves B.B., De Wit M.J. (Eds.). West Gondwana: pre Cenozoic correlations Across the South Atlantic region. Geological Society of London, 294:101-119.

Schobbenhaus Filho C., Campos D.A., Derze G.R., Asmus H.E. 1975 Carta Geológica do Brasil ao Milionésimo - Folha Goiás (SD 22). Texto explicativo. Brasília, DNPM, 114p.

Smith J.V., Brown W.L 1974. Feldspar minerals, crystals structures, physical, chemical and microtextural properties. Springer-Verlag, Berlin, 828p.

Trompette R. 1994. Geology of Western Gondwana, Pan-African/ Brasiliano aggregation of South America and Africa. A.A. Balkema, Rotterdam, Brookfield, $350 \mathrm{p}$.

Williams I.S., Claesson S. 1987. Isotopic evidence for the Precambrian provenance and Caledonian metamorphism of high-grade paragneisses from the Seve Nappes, Scandinavian Caledonides II. Ion microprobe zircon U-Th-Pb. Contributions to Mineralogy and Petrology, 97:205-217.

Available at www.sbgeo.org.br 